NBER WORKING PAPER SERIES

\title{
AMERICA'S FIRST GREAT MODERATION
}

\author{
Joseph Davis \\ Marc D. Weidenmier \\ Working Paper 21856 \\ http://www.nber.org/papers/w21856
NATIONAL BUREAU OF ECONOMIC RESEARCH
1050 Massachusetts Avenue
Cambridge, MA 02138
January 2016

We wish to thank Christopher Hanes, Joseph Ferrie, Lou Cain, and Marcelle Chauvet as well as seminar participants at UC-Riverside, Northwestern University, and the NBER for helpful comments and suggestions. We thank Ryan Shaffer for superb research assistance. The views expressed herein are those of the authors and do not necessarily reflect the views of the National Bureau of Economic Research or of the Vanguard Group.

NBER working papers are circulated for discussion and comment purposes. They have not been peerreviewed or been subject to the review by the NBER Board of Directors that accompanies official NBER publications.

(C) 2016 by Joseph Davis and Marc D. Weidenmier. All rights reserved. Short sections of text, not to exceed two paragraphs, may be quoted without explicit permission provided that full credit, including (C) notice, is given to the source. 
America's First Great Moderation

Joseph Davis and Marc D. Weidenmier

NBER Working Paper No. 21856

January 2016

JEL No. E01,E32,N1,N11

\begin{abstract}
We identify America's First Great Moderation, a recession-free 16-year period from 1841 until 1856, that represents the longest economic expansion in U.S. history. Occurring in the wake of the debt-deleveraging cycle of the late 1830s, this "take-off" period's high rates of economic growth and relatively-low volatility enabled the U.S. economy to escape downturns despite the absence of a central bank. Using new high frequency data on industrial production, we show that America's First Great Moderation was primarily driven by a boom in transportation-goods investment, attributable to both the wider adoption of steam railroads and river boats and the high expected returns for massive wooden clipper ships following the discovery of gold in California. We do not find evidence that agriculture (i.e., cotton), domestic textile production, or British economic conditions played any significant role in this moderation. The First Great Moderation ended with a sharp decline in transportation investment and bank credit during the downturn of 1857-8 and the coming American Civil War. Our empirical analyses indicate that the low-volatility states derived for both annual industrial production and monthly stock prices during the First Great Moderation are similar to those estimated for the Second Great Moderation (1984-2007).
\end{abstract}

Joseph Davis

The Vanguard Group

P.O. Box 2600, MS V13

Valley Forge, PA 19482-2600

joseph_davis@vanguard.com

Marc D. Weidenmier

Robert Day School of Economics and Finance

Claremont McKenna College

500 East Ninth Street

Claremont, CA 91711

and NBER

marc_weidenmier@claremontmckenna.edu 


\section{INTRODUCTION}

The Great Moderation is a term frequently used to describe the period of low macroeconomic volatility observed in the United States from 1984 until the onset of the global financial crisis beginning in 2007. The significant reduction in the volatility of real output over this period is also associated with less frequent and less severe U.S. recessions. Indeed, according to the National Bureau of Economic Research's monthly business cycle chronology, three of the four longest U.S. expansions following World War II occurred during the Great Moderation, including the 120-month expansion of the 1990s, commonly viewed to-date as the longest expansion in U.S. history.

Economists have generally offered one of three types of explanations for the marked decline in macroeconomic volatility between the mid-1980s and the late 2000s. Some have argued that improved monetary policy is a primary reason for the large drop in macroeconomic volatility (Stock and Watson, 2002; Bernanke, 2004). Other research has pointed to structural change that has made the economy less sensitive to shocks, including the shift of economic production from goods to services, improved management of inventory investment through information technology, and innovations in financial markets that promote intertemporal smoothing of consumption and investment (Blanchard and Simon, 2001; McConnell and Perez-Quiros, 2000). Several studies have also pointed to "good luck," or the absence of large shocks (i.e. oil shocks or limited large technology shocks) as important factors that help explain this period of unusually low business cycle volatility. While the sources of the Great Moderation certainly remain open to debate and require future research, the conventional wisdom is that there has only been “one” Great Moderation in U.S. history.

We break new ground in this paper by identifying America’s First Great Moderation. From 1841 until 1856, the United States experienced a 16-year economic expansion that was characterized by high economic growth rates (especially for investment goods such as transportation machinery) similar in magnitude to that of modern-day China. The U.S. economy escaped downturns during this period in part because economic growth was so high. Trend growth during the 1840s and 1850s in both Gallman's real GNP series and Davis' industrial production index were the highest of the nineteenth century. Economic and financial market volatility was significantly lower, too. We consult newer, high-frequency series in our statistical analyses, including annual industrial production (the most reliable indicator of business cycles for this period) and monthly stock prices (as an even higher-frequency indicator of financial conditions and panics). 
We test a number of hypotheses that could explain America’s First Great Moderation. Our empirical results suggest that the moderation was the result of the wider adoption and diffusion of transportation-oriented general purpose technologies (i.e., clipper and steam ships, locomotives and railroads). Through both Markov-switching models and Granger-causality tests, we show that the Great Moderation would not have occurred without transportation-related activity. Indeed, the reduction in the volatility of industrial production excluding transportation-intensive industries is less economically and statistically meaningful. In particular, America’s longest economic expansion may well have ended by 1850 had it not been for the discovery of gold in California, which significantly increased the expected returns for massive clipper ships that could sail to San Francisco in as little as one hundred days and from there circumnavigate the globe via the China trade. The spillover effects of this transportation boom were meaningful; indeed, the 1841-1856 period was unique in the pre-WWI era for transportationrelated output to lead the rest of the industrial sector.

Furthermore, we fail to find compelling evidence that agriculture (i.e., cotton), the weather, domestic textile production, immigration, or British economic conditions played any important role in causing America’s First Great Moderation. While we cannot rule out that certain other factorsincluding western expansion, increased financial market integration, lower and stable tariffs, and state constitutional reforms - may have played some role during this time, they likely would have had to have worked through the transportation sector and stock prices.

The paper begins with a brief history of the pre-Civil War economy of the 1840s and 1850s, especially in the context of early American business cycles. We then compare the First Great Moderation in economic and financial performance with other periods in the pre-World War I period. We employ Markov-switching models to assess the statistical significance of the decline in macroeconomic and financial market volatility that we observe during the First Great Moderation period relative to the fuller pre-WWI period.

Using similar IP and stock-price data, we then conduct an apples-to-apples comparison of our First Great Moderation to the modern-day Great Moderation that ran from the mid-1980s until the onset of the global financial crisis in 2007. Notably, our Markov-switching models reveal that the lowvolatility, high-growth states derived for the First Great Moderation (when America was truly an emerging-market economy) are of similar magnitude and statistical significance to those estimated for the contemporary one using comparable economic and stock-market data. Finally, we contemplate various factors — both structural and fortunate- that help explain the First Great Moderation. 


\section{THE ANTEBELLUM U.S. ECONOMY \& THE FIRST GREAT MODERATION}

\section{A. THE U.S. ECONOMY OF THE 1840s AND 1850s}

In the two decades prior to its Civil War, the American economy grew rapidly by nearly any measure in the Historical Statistics of the United States (U.S. Census Bureau, 1970). Between 1840 and 1860, the rates of immigration and the size of the U.S. labor force doubled, while the urban population tripled. Federal land sales and westward migration led to significant farmland development and growing transportation networks beyond the large eastern coastal cities. Agricultural output, such as for cotton, more than doubled over this time period.

While agricultural output accounted for more than one-half of economic output in 1840, the following two decades witnessed high rates of industrialization for the emerging-market economy. Annual growth in the Davis (2004) industrial production index averaged more than 6\% between 1840 and 1860, at least a full percentage point higher than the average growth rates in the twenty-year periods prior (1820-40) or after (1860-80).

The financial sector also expanded rapidly, leading to a notable increase in the number of banks,

publicly-traded securities, and volume of bank loans outstanding. Investment in transportation networks was both high and widespread for turnpikes, canals, railroads and maritime shipping routes.

\section{A1: High trend growth}

Some researchers consider this unique period in American economic history as its "take-off” period. Such high rates of economic growth are clearly evident in Table 1, which presents Gallman’s (1966) estimates for trend U.S. real GNP. The Gallman GNP data are arguably the most comprehensive and reliable estimates of trend growth for the antebellum U.S economy (Rhode, 2002). Gallman assembled his national product estimates from Census and other sources in the mid-1960s to provide a clearer picture of the long-run performance of the U.S. economy.

As illustrated in Table 1, U.S. real GNP grew at more than a 5\% annualized rate between the mid-1840s and late 1850s, versus still-high yet lower rates of growth during the development of the U.S. economy in the late 1800s. In short, the decades of the 1840s and 1850s witnessed the most robust rates of economic growth of the nineteenth century. Indeed, per capita GNP rose more than 30\%. 


\section{A2: Integration of financial and labor markets}

The high rates of economic growth during the 1840s and 1850s were also accompanied by more integrated financial and labor markets. Financial integration improved markedly as illustrated by differences in interest rates across major U.S. cities (Table 2). Bodenhorn (1992, 2000) shows that while interest rates were high and volatile at the beginning of the Free Banking Period (1837-1862), regional interest rates converged over the course of the 1840s. Comparing New York City and Charleston, Bodenhorn demonstrates that interest-rate differentials for the two cities hovered around zero from 1844-1857 (before the panic), despite the geographic distance.

Increased financial market integration could also have played a role in the high rates of capital investment during the 1840s and 1850s by reducing business uncertainty and raising confidence. Davis (1960), for example, finds that more stable credit markets (i.e., smaller fluctuations in short-term interest rates) promoted growth in New England textile mills in the two decades prior to the Civil War.

Labor markets became increasingly integrated during the 1840s and 1850s as well. Partly aided by western migration and increased intra-regional capital and goods flows, real wages converged across the country and became less volatile, forming the beginnings of a more efficient and integrated "national labor market” (Margo 1998, 1). Margo (1999), for instance, shows that while in the 1830s Midwestern real wages for common labor were 30.5 percent higher than in the East, this value had dropped to 10.1 percent and 11.4 percent in the 1840 s and 1850s, respectively. ${ }^{1}$

\section{A3: Business cycles between the 1830s and the Civil War}

A fast-growing and more-integrated economy with advancing capital markets would seem to suggest the U.S. experienced less frequent and less violent downturns during the 1840s and 1850s. Qualitatively, however, the early foundations of today's official NBER business-cycle chronology suggest a volatile economy. According to Thorp’s Business Annals (1926) and Burns and Mitchell’s Measuring Business Cycles (1946) — two seminal NBER studies that laid the groundwork for the official monthly NBER business-cycle dates before 1920 — the U.S. economy spent nearly every other year in recession between the late 1830s (following the Panic of 1837) and the onset of the Civil War. The depression of 1839 is believed to not have ended until at least 1843 and perhaps as late as 1845. Recessions and panics are noted for 1846, 1848, and 1854. Based more on anecdotal newspaper reports

\footnotetext{
${ }^{1}$ In addition Vandenbroucke (2008) demonstrates that western/eastern real wage ratios, which had widely varied prior to the early-to-mid 1840s, declined and remained relatively stable for the remainder of the antebellum period.
} 
than economic data, the Annals tend to reflect financial market conditions and price corrections rather than business cycles. ${ }^{1}$

Other classic treatments of the nineteenth-century financial markets, such as Kindleberger (2000), refer to a number of financial panics during the late 1830s, 1840s, and 1850s that were believed to have led to significant recessions, deflation, and, at times, depressions. Indeed, we would argue that such characterizations are taken as "fact" in contemporary economic and history textbooks. At first glance, such descriptions would seem inconsistent with a great moderation, and appear to run counter to a period of high trend growth.

The reliability of these qualitative accounts of pre-Civil War business cycles and volatility is, of course, debatable given the paucity of economic data that previous researchers had access to. Today, the NBER does not officially record monthly business cycle peaks and troughs in U.S. economic activity prior to December 1854 for precisely this reason. ${ }^{2}$

To be sure, subsequent research strongly suggests that some of the perceived business-cycle properties for the post-Civil War American economy are inaccurate. Romer (1994) demonstrates that, contrary to modern NBER practices, the monthly peaks and troughs between 1884 and 1927 were derived using detrended data that dated peaks earlier and troughs later vis-à-vis post-WWII turning points. Davis (2006) concludes that some post-bellum NBER recessions did not occur at all. Watson (1994) shows that when post-WWII cycles are based solely upon nominal price data for commodities and financial variables, one finds only marginal differences between postbellum pre-WWI and postWWII cyclical variations. Naturally, these studies raise questions regarding the perceived high level of business-cycle volatility and high frequency of recessions during the pre-Civil War period, whose accounts were based on even scantier data.

\section{B. DATA}

In this study, we consult newer, high-frequency series in our statistical analyses on the early American business cycle, including annual industrial production and monthly stock prices. With access to better data, we locate America’s First Great Moderation.

\footnotetext{
${ }^{1}$ By consulting contemporary newspaper accounts and fluctuations in commodity and stock prices, Thorp's Business Annals for instance summarizes business conditions in 1845 as "prosperity; brief recession,” 1846 as "recession, mild depression,” 1847 as "revival; prosperity; panic; recession,” and 1848 as “mild depression; revival.”

${ }^{2}$ See, for instance, Moore and Zarnowitz (1986).
} 


\section{B1: Annual U.S. industrial production}

Our primary measure of the business cycle during America's First Great Moderation is the Davis (2004) quantity-based industrial production (IP) index, the most reliable broad measure of U.S. real output for the pre-Civil War period. The Davis IP index is comprised of 43 annual components in the manufacturing and mining industries that are consistently defined from 1790 until World War I. It is a comprehensive industrial output measure in so far as its components directly or indirectly represent close to 90 percent of the value added produced by the U.S. industrial sector during the nineteenth century. Changes in the Davis IP index reflect only fluctuations in real output.

While the Gallman real GNP data shown in Table 1 are somewhat more comprehensive than the Davis IP index, the annual estimates themselves are far less reliable. Gallman himself did not trust the accuracy of his annual time series, declining to ever publish them and instead using them to infer trends in antebellum growth. As Rhode (2002) notes, Gallman was adamant to fellow researchers when using his provisional and unpublished estimates that they cite verbatim the statement "that these data were not constructed for analysis as annual series," and even stressing in a 1963 mimeo "NOTE: These figures should not be regarded as reliable, annual estimates." 1

Figure 1 charts logarithmic growth rates in the Davis IP index from 1790 through 1915. In the figure we highlight the 1841-1856 period, which we will call America’s First Great Moderation. Table 3 compares the average growth rate in real output (as defined by the annual Davis IP index) during the First Great Moderation (1841-1856) with the sample periods before and after its occurrence.

Based on the annual Davis IP series, we find that economic growth averaged nearly 8 percent per annum during the First Great Moderation, compared to an average growth rate of approximately five percent for the rest of the 1792-1914 period. Overall, the growth rate of IP was sixty percent higher on average during the First Great Moderation than in either of the preceding or subsequent sample periods. This acceleration in industrial growth parallels and corroborates the acceleration in growth of Gallman's real GNP series in Table 1.

During the antebellum period, the differences in average growth rates between the Great Moderation and other years are statistically significant $(\mathrm{p}=0.04)$, compared to insignificant differentials between the antebellum and post-bellum periods (see bottom of Table 3). One would expect average

\footnotetext{
${ }^{1}$ As discussed in Rhode (2002) and Davis (2002), other provisional GNP estimates for the pre-Civil War economy (such as Berry's series) are even less reliable and are inappropriate to date business cycles. By contrast, the Davis index incorporates new source data across a host of sectors that had direct ties to the agricultural and export markets of the early U.S. economy.
} 
economic growth to be higher during the First Great Moderation since there were no absolute annual declines in industrial production between 1841 and 1856.

The high rate of economic growth in industrial production was accompanied by low economic volatility. The standard deviation of economic growth was 5 percent between 1841 and 1856. For the antebellum period before the start of the First Great Moderation, the standard deviation of industrial production growth averaged 6.7 percent. The standard deviation of IP growth averaged 7.5 percent in the post-bellum period. The volatility of economic production was at least 20 percent lower during the First Great Moderation. As is the case with mean growth rates, volatility differences in IP growth between the Great Moderation and pre-GM antebellum years are statistically significant $(\mathrm{p}=0.098)$, compared to insignificant differentials between the antebellum and post-bellum eras.

We also employ the coefficient of variation (standard deviation divided by the mean) to control for the fact that the average growth rate in IP was higher during the First Great Moderation. Table 3 shows that the coefficient of variation for industrial production during the First Great Moderation, at 0.65, was notably lower when compared to 1.45 for the antebellum period and 1.63 for the post-bellum period. This suggests that macroeconomic volatility was at least 25-30 percent lower during the First Great Moderation than other periods. The basic summary statistics suggest that economic growth was higher and macroeconomic volatility significantly lower during the First Great Moderation.

\section{B2: Monthly U.S. stock prices}

Importantly, we corroborate our annual IP-based results using a monthly series on stock prices, which should afford an even higher-frequency indicator of financial conditions and "panics” sometimes cited in the qualitative characterizations of the contemporary economy.

Specifically, we employ Goetzmann, Ibbotson, and Peng's (2005, hereafter GIP) pre-CRSP era stock index from 1815-1914 to examine stock returns and stock volatility during the First Great Moderation. The GIP pre-CRSP era NYSE series is among most comprehensive monthly stock market series for the nineteenth century. While other city-level stock price series exist for the antebellum period (Schwert, 1990), we focus on the GIP series since it spans the entire nineteenth century and tends to include more securities than other stock indices, such as Smith and Cole’s price index.

Figure 2 shows monthly stock returns before, during and after the First Great Moderation, which is shaded. During the 1840s and 1850s, the securities in the GIP index pertained primarily to financial companies (insurance companies, banks) and railroad companies. 
Table 4 shows that average (arithmetic) stock returns averaged 0.3 percent per month during the Great Moderation. Average stock returns for the GIP Index were negative in the antebellum period before the Great Moderation, and averaged 0.17 percent per month in the post-bellum period. Stock volatility, as measured by the standard deviation of monthly price returns, averaged 3.5 percent during the First Great Moderation, compared to 3.9 percent and 4.0 percent in the antebellum and post-bellum periods, respectively. The lower stock-market volatility for the Great Moderation is statistically significant and is more than 20 percent lower than the non-Great Moderation antebellum period and more than 10 percent lower than the post-bellum period.

The coefficient of variation for stock returns during the First Great Moderation, 11.44, is approximately one-half that of the coefficient of variation for either the earlier antebellum period (25.78) or post-bellum period (23.35). Overall, we find that stock returns were both higher and significantly less volatile than the rest of the pre-World War I period. This result is clearly visible when examining the monthly NYSE returns in Figure 2.

\section{C: IDENTIFYING BUSINESS CYCLES}

\section{C1: IP versus GDP}

Focusing on industrial production—rather than broad GDP or even nonagricultural GDP—could be a potential limitation of our study if (and only if) IP was not reflective of the broader economy during this era. We argue that this was not the case, for at least four reasons.

First, as discussed in Davis (2004), IP is appropriate to define the historical evolution of U.S. business cycles, if for no other reason than the fact that America's emergence as an economic power is commonly equated with its industrialization. While more than one-half of national output in the antebellum United States was agricultural, the Davis IP index should broadly indicative of the nation's broader economic conditions because the industrial sector has historically derived demand directly from nonindustrial occupations, particularly farmers, merchants, and the construction trades. ${ }^{1}$ The processing of foodstuffs, the demand for agricultural machinery, and the capital equipment required to transport agricultural commodities to market are all intimately tied to farm output and the relative price of agricultural goods, even though agricultural production is often characterized as acyclical. Likewise, the

\footnotetext{
${ }^{1}$ The contemporary equivalent would be to acknowledge that a major oil-producing economy’s non-energy sectors will be negatively impacted when its domestic energy production contracts.
} 
manufacture of lumber products and transportation equipment were acutely sensitive to business conditions in the construction trades, the railroad industry, and inland transportation sectors.

Second, some of the most severe contractions in the Davis IP index (such as 1808) were the result of a significant shock originally to the non-industrial sector that could have benefitted IP if IP was not so reliant upon (and reflective of) broader economic conditions. A prime example is the deep recession of 1808, when the Davis IP index contracted nearly 19\% (!) given the collapse of the shipbuilding and foodstuff industries that were heavily dependent upon the health of the maritime trades and Britain’s export market. Indeed, the nonintercourse period following the Embargo of 1807 had a devastating impact on the economy (despite temporarily stimulating some infant industries) and led to the largest annual decline in the Davis IP index in the pre-Civil War era.

Third, the NBER today includes industrial production (and not GDP) as one of the four primary coincident indicators to identify and date U.S. business cycles. While IP is less comprehensive than GDP, it is both valuable and accurate in identifying turning points today since manufacturing is a highly-cyclical sector, in the same way it was for the antebellum period. This is important considering that the economy's share of output in the industrial sector over the past three decades (roughly 20\%) was similar to its share between the 1840 and 1860.

Finally and perhaps most persuasively, every downturn in annual real GDP since WWII has been accompanied by an annual decline in IP. Put another way, we view a downturn in IP as both a necessary and sufficient condition for a recession during the nineteenth century.

\section{C2: Longest expansion in U.S. history}

We employ the Davis IP index to evaluate the reliability of Thorp's annual business cycle dates during the First Great Moderation. Specifically, we construct an alternative set of annual peaks and troughs between 1796 and 1914 as defined by absolute rises and declines in the annual IP index. A comparison of the NBER annual business-cycle chronology with this alternative set of peaks and troughs for the entire 1800s is reproduced from Davis (2006) in Table 5.

The resulting Davis chronology alters more than 40 percent of the peaks and troughs, and removes those cycles long considered the most questionable by various economists, including Friedman and Schwartz (1963), Temin (1969), and Zarnowitz (1992). ${ }^{1}$ As a result, the new annual peaks and

\footnotetext{
${ }^{1}$ We confirm Temin's $(1969,156)$ suspicion that the downturn following the Panic of 1839 was neither long nor severe in terms of real output since the sharp decline in prices and wages "may have substituted for falling production in the early
} 
troughs reduce the average frequency of nineteenth-century recessions from nearly every other year in the NBER set, to one out of five years. The years 1846, 1847 and 1848 that Thorp classified as potentially brief recessions saw, instead, industrial production grow at double-digit rates. No recessions occurred during these years.

Most notably, the alternative chronology in Table 5 reveals that the period from 1841 until 1856 was a 16-year, recession-free period, the longest U.S. economic expansion in American history. This alone would seem to qualify the years between 1841 and 1856, inclusive, as America’s First Great Moderation.

\section{COMPARING TWO GREAT MODERATIONS}

Given the importance of our result, we examine its robustness in two (related) ways. First, we judge how America’s Second (modern-day) Great Moderation looks using comparable annual IP fluctuations. Second, we estimate Markov regime-switching models to assess the statistical significance of America’s First Great Moderation, and again compare those estimated results to same-frequency IP and stock-price data observed for the Second Great Moderation.

\section{D1. Recessions, output gaps and growth recessions}

We can get a general sense of the magnitudes of the two Great Moderations by creating trailing growth-to-volatility ratios in an annual IP index that spans both. We accomplish this by creating one extended annual IP series from 1790 through 2010 according to the procedures recommended in Davis (2004). Specifically, we can ratio-splice the annual Davis IP index to the Miron-Romer IP index in 1916 before ratio-splicing to annual values of the Federal Reserve IP index beginning in 1919. While we stress that we cannot conduct a formal statistical volatility break-point test on this long series given changes in series comparability and reliability over time, the signal-to-noise ratio in Figure 3 allows us to visually gauge changes over rolling 20-year periods.

Clearly, Figure 3 suggests that the combination of high IP growth and lower IP volatility during America's first Great Moderation-expressed as a trailing growth-to-volatility ratio (or, signal-to-noise ratio) — appears to have been as impressive in scale as America’s second (modern-day) Great Moderation when measured against similar annual IP index data from the Federal Reserve. 
We can also examine the business-cycle properties in the Second Great Moderation by dating recessions in a similar manner as was done in Table 5-that is, simply by declines in the annual IP index over the 1980-2010 period. As can be seen in Table 6, the recessions of 1991, 2001, and 2008-2009 clearly show up in the Federal Reserve's annual IP data.

We can also identify so-called "growth recessions” in either of the Great Moderation periods by calculating deviations from the trend in the annual log IP series (i.e., an "IP gap”) of the Davis and Federal Reserve series, respectively. To span most definitions of fluctuations versus trends, we estimate trends two ways: (1) a one-sided, backward-looking Hodrick-Prescott (HP) filter, and (2) a two-sided HP filter that possesses look-ahead bias.

Table 6 shows that while America’s First Great Moderation did not involve an outright decline in real output, the U.S. economy did experience several so-called "growth recessions” at times when real output increased at a below-trend pace. Important examples during the First Great Moderation include the early 1840s following the Panic of 1839, as well as respites from otherwise strong growth in the late 1840s and the mid-1850s, periods that Thorp misclassified as recessions (see also Davis (2006)).

For the Second Great Moderation, similar growth recessions persist through roughly half of the 1984-2007 period. Using a one-sided real-time measure of deviation from trend, the U.S. economy did not grow above trend in any year between 2001 and 2010.

\section{D2. Markov regime-switching models for annual IP}

In this section, we estimate Markov regime-switching models to assess the statistical significance of changes in real economic volatility (high vol, low vol) before, during, and after the First Great Moderation using logarithmic growth rates in annual IP growth (1792-1914). We then compare our results to America’s Second Great Moderation using similar data and techniques for the post-WWII period.

Our primary specification is a univariate autoregressive non-linear Markov-switching model with two regimes. In particular, we assume that annual IP growth, $\Delta y_{t}$, depends on two underlying and unobserved states, $V_{t}, t=1,2$, such that:

$$
\Delta y_{t}=\mu_{V_{t}}+\phi_{V_{t}} \Delta y_{t-1}+\varepsilon_{t}, \quad \varepsilon_{t} \sim N\left(0, \sigma_{V_{t}}\right) \text {. }
$$

At first pass, we allow the means, variances and autoregressive parameters to all vary between two states. We then also impose a constant-mean restriction based on the equality-of-means tests in Table 2, still allowing the variance and autoregressive parameters to vary between two states. 
The Markov-model results for annual IP growth over the entire pre-WWI, 1792-1914 sample are reported in Table 7 for both constant mean (Panel A) and switching mean (Panel B) specifications. In each panel, all estimated parameters are statistically significant at the 10 percent significance level or better, with significant differences in volatility between the high-volatility and low-volatility states. Annual IP volatility in low-volatility regimes was approximately one-fourth that of high-volatility regimes, which on average had a modestly longer duration of approximately 4 years. The differences in average switching mean growth rates in Panel B are not economically or statistically meaningful and close to the constant mean growth rate of 4.29 percent per annum in Panel A. For this reason, we chose a constant mean as our baseline Markov-switching specification for the remainder of this paper.

Table 8 compares the constant-mean results for the 1792-1914 period (Panel A, Table 7) with those for annual IP data for the 1950-2010 sample. The results for the modern-day period using annual IP data are listed in Panel B. While the estimated standard deviation in the low-volatility state is marginally significant ( $\mathrm{p}=0.12$ ), the expected duration of low-volatility regimes is longer in the post1950 sample (6.65 years) and the standard deviation of the low-volatility state is almost $1 / 25^{\text {th }}$ the size of the high-volatility state.

Panels A and B of Figure 4 shows the smooth low-volatility state probabilities from the Markov models for the annual growth rates for the Davis and Federal Reserve Board indices. Clearly, our constant-mean specification is not restrictive for either period, as the estimated probabilities are nearly identical under either a constant-mean or switching-mean model.

Panel A in Figure 4 confirms that the First Great Moderation began in the early 1840s and ended in 1857, with the probability of a low-volatility state rising to nearly 90 percent in the late 1840s and early 1850s. This peak during the First Great Moderation is higher than at any other time during the 1792-1914 period. In a similar fashion, the probability of a low volatility state is highest during America’s Second Great Moderation. Again, the probability of a low-volatility state peaks during the mid to late 1990s and early 2000s.

Figure 4 compares the First Great Moderation with the Second Great Moderation by plotting the ratio of the conditional mean to the conditional standard deviation for the growth rate of the two industrial production series. The growth rate of the two IP series shows a spike in the ratio that coincides with a Great Moderation in the pre-WWI era as well as one in the modern era. By this metric, the First and Great Moderations were very similar in relative magnitudes. 


\section{D3. Markov regime-switching models for monthly stock returns}

Table 9 reports the results of the Markov-Switching models using equation (1) for monthly stock returns in the pre-WWI (Panel A) and post-WWII (Panel B) periods. The average stock return for the GIP Index was 0.18 percent for the entire sample period. The probability of remaining in the low volatility state is 91 percent, versus 71 percent in the high volatility state. The standard deviation of stock returns in the low volatility state (0.06) was 88 percent lower than in the high volatility state (0.51). The differences of the standard deviations are statistically significant at the one percent level. The expected duration of the low-volatility state is 11.65 months compared to 3.4 months for the high volatility state. As for the modern period, the average stock return is 0.69 percent. The standard deviation of stock returns in the high volatility state is more than four times higher than the low volatility state. Both the high and low volatility states are highly persistent. The expected duration of the low-volatility regime is almost 20 months compared to seven months for the high-volatility state.

Figure 6 shows the smoothed probabilities from the Markov-switching models on monthly stock returns. Panel A clearly shows that the probability of a low-volatility state was quite high during the First Great Moderation. The smoothed state probability is nearly 90 percent for the long economic expansion. This stands in contrast to the post-bellum period, where smoothed low-volatility state probabilities rarely exceeded 80 percent for almost the entire period after the end of the Civil War. Finally, the post-WW II sample suggests that there were two periods of low volatility in stock returns: (a) 1950s-1960s and (b) most of the 1990s that coincides with the Second Great Moderation.

\section{EXPLAINING THE FIRST GREAT MODERATION}

\section{A. GREATER ADOPTION OF GENERAL PURPOSE TECHNOLOGIES}

We hypothesize that a primary factor for the Great Moderation in both manufacturing and in the U.S. stock market was the diffusion of general purpose technologies centered in the transportation sector. Such technological diffusion would have generated spillovers in the form of increased investment, larger and more integrated product and labor markets, and increased western migration within the United States. Indeed, the First Great Moderation was characterized by the accelerated adoption of three important transportation and communication technologies: (1) the steam locomotive and railroad, (2) faster clipper and steam ships, and (3) the telegraph. 
Such high rates of productivity growth, which indeed did appear to occur during the First Great Moderation as illustrated in Figure 7, would also be consistent with endogenous growth models that account for the diffusion of such broad-based technologies.

General purpose technology (GPT) is defined as technological innovation that can have large and wide-ranging macroeconomic impacts, such as the steam engine, electricity, or the computer (David, 1991; Helpman, ed., 1998). While the initial emergence of a general purpose technology (GPT) can be associated with lower and more volatile productivity growth via creative destruction and increased R\&D, Helpman and Trajtenberg (1996) show that the eventual wider adoption of a GPT across economic sectors can culminate in a "second wave" of investment and bringing about a spell of sustained growth, similar to that seen in Figure 7. Aghion and Howitt (1998) extend the HelpmanTrajtenberg model where to account for stages of component building and network spillovers in the technology diffusion process. In the Aghion-Howitt model, cyclical fluctuations and the magnitude of slumps in economic growth can decline markedly for an extended period if either intermediate inputs become more substitutable and profitable, or if the productivity (and real income) gains from such new technologies are sufficiently "large.”

\section{B. TRANSPORTATION REVOLUTION OF THE 1840s AND 1850s}

According to Taylor (1951), the 1840s and 1850s marked a "transportation revolution" in the antebellum U.S. economy that witnessed strong gains in productivity and high levels of investment. Trend economic growth was high in part due to high rates of both public and private investment in expanding transportation networks for roads, canals, railroads, and global shipping routes.

\section{B1. The shipbuilding boom}

During the 1840s and 1850s, American shipyards built more merchant tonnage than what was built in the previous four decades combined. Indeed, the zenith in merchant tonnage constructed in 1854 and 1855 would not be surpassed until World War I.

A primary factor in this surge in shipbuilding investment was the clipper ship, an extremely fast ship that possessed flatter hulls, sharper bows and could routinely accommodate more than two thousand tons in cargo. The discovery of gold in California in 1848 led to an immediate jump in the expected rates of return on fast ships that could expediently carry large cargoes to San Francisco and, rather than carry ballast back home could rather circumnavigate the globe by sailing from the Pacific on toward China

(for its valuable tea) or even Hawaii (for whaling). The fastest clipper ships built in the 1850s in the 
shipyards of New York, Boston, Philadelphia and Maine could cost nearly \$100,000 or more to construct at the time, but they could sail from the eastern coast to San Francisco via the Cape Horn in as little as 90 days. One round-trip could net a profit for ship owners equal to the entire cost of construction (Howe and Matthews, 1986).

The period from the late-1840s through the mid-1850s is generally known as the "Clipper Ship Era.” The production of clipper ships increased from an index value of 58 in 1841 to a value of more than 158 in 1856 . The period 1850 until 1856 represented the high point period -an index value of 266 in 1854--for the clipper ship which benefitted from the gold rush in California and the China trade. Clipper ship production started to wane in 1857 as the clipper ship gradually gave way to steam powered ships that could carry heavier loads across the Atlantic and Pacific Oceans. The boom in clipper-ship construction had a significant stimulative impact on the U.S. lumber industry, with many coastal timber fields being exhausted during the 1850s given the incredible demand for lumber products to construct the large wooden ships.

Steam ship trade also experienced a take-off during the First Great Moderation. The number of steamships involved in the Atlantic trade increased from 5,631 tons in 1847 to 97,296 tons in 1860 (Taylor, 1951, p. 116). Steamships garnered the bulk of the Atlantic trade by the end of the antebellum period. Steamship construction also accelerated for the trade along the Mississippi River as western migration expanded Midwestern markets. American merchants, on the other hand, generally continued to use sailing ships in the antebellum period.

\section{B2. Steam locomotives and expanding railroad networks}

Steam power was also used to power rolling stock during the antebellum period. Although steam engines were introduced to the United States with the Baltimore and Ohio Railroad in 1828, the railroad took approximately two decades of innovation and capital investment to have a significant impact on the antebellum economy. Prior to the 1840s, canals served as the primary means of transportation for shipping commodities, especially from the West. The creation of the Erie Canal in 1817 posed the first serious challenge to previous transportation systems such as turnpikes, and allowed greater access to western hubs from New York and New England. Freight rates over the Erie Canal quickly decreased to an average of 1.68 cents per ton-mile for eastbound freight and 3.35 cents for westbound (Taylor, 1951). By comparison, freight rates for railroads in the mid-1830s were often 7-10 cents per ton-mile (Fishlow, 1965). Rail mileage accelerated through the 1830s and 1840s, reaching 3,328 miles in 1840 and 8,879 
by 1850 . Railroad mileage by 1850 had also outpaced canals in 25 states, including major production hubs like New York and Massachusetts. Both experienced an increase in tonnage in the West, but for water routes this was largely the result of massive Western migration, which increased demand across the board. This technological-diffusion process accelerated with the construction of almost 22,000 miles of track built in the 1850s. By the eve of the Civil War, railroads had replaced canals as the predominant means of transportation.

Railroads had a major impact on agricultural productivity in the 1850s (Fishlow, 1965). Atack and Margo (2009) determined that even under the most conservative estimates, railroads were responsible for at least 25 percent of acreage improvements in the 1850s. Atack, Haines, and Margo (2008) find that rail access had a significant effect on the development of factories in the 1850s. Increased investment in locomotive and railroads during the late antebellum period may have also further stimulated the westward migration of labor and agricultural productivity. Ferrie (1997), for instance, found that moving to the frontier translated into a 45 percent gain in real wealth during the 1850s, indicating that it was advantageous for at least some migrants to head west.

\section{SOURCES OF THE GREAT MODERATION IN INDUSTRIAL PRODUCTION}

To test our hypothesis that transportation played a critical role in America’s First Great Moderation, we create special sub-indices of the Davis IP series.

\section{C1. Sector-specific industrial production indices}

First, we decompose the Davis IP index into two broad, mutually-exclusive sub-indices - an investment goods IP index and a consumption goods IP index. The investment goods index consists mostly of durable goods, including metal-producing sectors, transportation machinery, other small machinery categories, and the lumber industry. The consumption goods index consists of the food, textiles, printing, chemical/fuels, and leather-producing sectors. ${ }^{1}$ In 1850 , the consumption goods industry accounted for approximately $60 \%$ of the total value added in the manufacturing and mining sectors, while manufacture of investment goods yielded the remaining $40 \%$ of industrial production.

We construct even finer-level IP indices from both the investment and consumption goods IP indices. For consumption goods, we create two IP indices—an IP food products index (accounting for

\footnotetext{
${ }^{1}$ These sector classifications are similar to how the Federal Reserve today distinguishes between longer-term and generally more volatile durable-goods investment, and investment in and production of nondurable goods.
} 
$10.9 \%$ of the value-added in the industrial sector in 1850) and an IP textiles index (21.8\%), which is primarily comprised of the cotton consumed by domestic textile mills. During this period, the textile sector was the largest industry on both a gross and value-added basis.

For investment goods, we create an IP metals index (accounting for $12.9 \%$ of the value added in 1850) and an IP transportation-intensive index (22.7\%) comprised of locomotive production, shipbuilding, and the primary input by far to ship construction at that time, lumber. Finally, we created an IP index excluding transportation-intensive sectors that accounts for the remaining series in the Davis IP index, accounting for $77.3 \%$ of that index on a value-added basis.

We then calculate growth rates, standard deviations, and coefficients of variation for all of these IP series as we did for the aggregate index. The summary statistics are reported in Table 10. Several important features emerge. First, both consumption and investment goods had higher rates of average growth during the Great Moderation than either before or after, although the boom in investment goods during the 1841-1856 period is much stronger, with growth in the transportation IP index averaging 10 percent per annum versus only 3 percent per annum in the 1792-1840 period.

Second, the U-shaped pattern in volatility for the Davis IP index-lower volatility during the Great Moderation versus the periods before and after-is observed for investment goods but not for consumption goods. The standard deviation in transportation-related production declines by one-third between the antebellum (0.179) and Great Moderation period (0.115) before nearly doubling in the postbellum period (0.207). The decline in volatility in metals production is less pronounced and more monotonic throughout the 1828-1914 period. ${ }^{1}$

Third, the combination of higher growth and even lower volatility for investment goods leads to a pronounced U-shaped pattern in the coefficient of variation for the investment goods IP index. The coefficient of variation for investment goods is 0.81 for the Great Moderation, or 80 percent lower than that for the earlier antebellum period (4.15) and nearly one-third lower than the post-bellum period (2.65). This U-shaped pattern in the coefficient of variation is even more striking for the transportationgoods sector, with a ratio of 1.15 during the Great Moderation a fraction of that observed either before (6.02) or after the Civil War (14.08). Overall, the summary statistics in the top half of Table 10 would suggest that transportation-related investment contributed to the emergence of America's First Great Moderation.

\footnotetext{
${ }^{1}$ The IP metals index commences in 1827 given the limitations in pig-iron data.
} 


\section{C2. Markov models for sector-specific IP series}

We test our hypothesis that transportation-related investment was the primary source of the recession-free period from 1841-1856. Again, we estimate the Markov regime-switching model on the IP indices that exclude textiles, transportation, and investment/consumption goods, respectively. In doing so, we can assess whether the exclusion of a primary sector (i.e., transportation or textiles) significantly weakens the probability that the Great Moderation would have occurred.

The estimated coefficients of the Markov models can be found in Table 11. Focusing on both the statistical significance of the coefficients as well as the ratios in estimated standard deviations between the low- and high-volatility states, one can see that the results for IP excluding textiles and for IP investment goods are similar (if not stronger) when compared to the Davis IP index in Table 8. Conversely, the model results are much weaker when one excludes transportation investment and investment goods, more broadly. For the IP consumption goods index, the average standard deviation in the low- and high-volatility states are very similar (0.003), while the estimate for the low-volatility state for the IP index excluding transportation is not statistically different from zero.

Figure 8 displays the probabilities these series where in low-volatility states over time based on the model results in Table 11. Most notably, the Great Moderation we find for the Davis IP index is much weaker when one excludes transportation-goods investment, with only the 1843-1849 period possessing probabilities above 50 percent. The implication is that without transportation investment, the U.S. economy would have only experienced a moderate expansion that ended before 1850 and would not have experienced the high growth of the 1850s.

Second, the Great Moderation in investment goods is clearly evident in Figure 8; before 1841 the investment goods sector was rarely estimated to have been in a low-volatility state compared to the broader Davis IP index. Third, the results for the IP index excluding textiles in Figure 8 suggest that the Great Moderation may have persisted even longer had there not been more significant and negative impacts from the volatility in cotton textile production in the late 1850s.

Finally, Figure 9 presents the ratios of conditional mean to conditional standard deviations (signal-to-noise ratio) as estimated by our Markov model for each of the series. The top-right panel of the figure shows that the combination of higher growth and lower volatility during the Great Moderation was the most pronounced for investment goods and the weakest when we exclude transportation-related investment from the Davis IP index. 


\section{C3. Transportation investment led all other IP, not vice versa}

The Markov-based results strongly suggest that the boom in transportation investment was a key contributor to America’s First Great Moderation. To better infer such investment spilled over to or led other economic activity, we run bivariate Granger-causality tests between each of the four key sectors (all investment goods, transportation, metals, as well as textiles) on all other IP. We run these tests for the entire 1792-1914 sample, as well as for three sub-samples. The results are presented in Table 12.

First, we find transportation IP led all other IP during the Great Moderation period at the 0.01 significance level, while all other IP did not lead fluctuations in transportation production. Transportation IP statistically led growth in consumption-goods output, too, during the Great Moderation ( $\mathrm{p}=0.03$ ). Second, the results are exactly the opposite for textiles and metals, where all other IP led textile and metal IP during the Great Moderation at the 0.02 and 0.05 significance levels, respectively.

Third, growth in transportation-related IP did not lead all other IP growth during the postbellum period; rather, the lead relationship ran in the opposite direction. Put differently, the 1841-1856 period was unique in how the boom in transportation investment contributed to a period of higher growth and lower volatility. To illustrate, Figure 10 presents F-statistics from Granger-causality tests between transportation IP and all other IP over rolling 15-year windows beginning in the early 1800s through 1914. The line demarcates the observation that spans the Great Moderation period. The lines show that the strong lead relationship from transportation goods to the broader industrial sector was somewhat unique to the Great Moderation period.

\section{INVESTIGATING AGRICULTURAL AND TRADE CHANNELS}

We can use both Markov regime-switching models and Granger-causality tests to examine whether other candidates outside of transportation-related investment help explain the First Great Moderation. Here, we focus on three-(1) the domestic cotton crop, (2) tariff rates, and (3) British economic conditions.

Despite the rapid industrialization of the American economy at this time, agriculture was still its largest sector. Cotton was not only the nation's most significant export, but it was also the primary input to America’s largest industry_-cotton textile mills. Shocks to demand or supply (i.e., weather) to the cotton crop could have had important effects on the business cycle. To be sure, in the post-bellum period 
under the gold standard, Davis et al (2009) find that most major U.S. recessions between 1880 and World War I were caused by fluctuations in the size of the cotton harvest due to exogenous factors such as weather.

Another factor that may have contributed to stable economic growth during the First Great Moderation was the sustained downward trend in U.S. import tariffs beginning during the early 1830 s and running until 1860. According to Irwin (2008), import tariffs were steadily and consistently reduced over time due to the shifting political coalitions between the various regions of the country. Finally, growth and fluctuations in the British economy may have played a leading role in a less-volatile U.S. economy. Great Britain was the world’s largest economy and was America’s most important trading partner.

Figure 11 displays the probabilities of being in a low-volatility state for the growth rate in the U.S. cotton crop, growth in British industrial production, and simple differences in U.S. tariff rates. The specification of the Markov regime-switching model is identical to those used for U.S. IP and stock prices except for in the case of the cotton crop, where we allow for three volatility states given the extremely-high volatility levels during the Civil War. ${ }^{1}$ As illustrated in the figure, neither the cotton crop nor British IP display any meaningful structural breaks in volatility during America’s First Great Moderation; rarely is the British economy in a low-volatility state at this time. Changes in tariff rates, on the other hand, do show a significant break toward lower volatility around 1847 which persists until the Civil War.

Nevertheless, none of these three variables (cotton crop, tariffs, or British IP) lead changes in overall U.S. industrial production during the First Great Moderation. Table 13 displays the statistical results under the hypothesis that each of these three variables (individually) led fluctuations in several U.S. industrial production indexes. Fluctuations in the cotton crop led fluctuations in U.S. textile production, but not in either investment goods nor in overall industrial production. This is consistent with not only our previous finding that textile production did not lead changes in overall industrial production at this time (Table 11), but also that the First Great Moderation would have hypothetically lasted beyond 1856 if the industrial sector had excluded textiles (Figure 8). Table 13 also shows no meaningful relationship for either British industrial production or tariff rates on the large U.S. industrial sectors we focus on here. Between 1840 and 1860, the contemporaneous correlation between annual fluctuations in British and American IP was low, at 0.36.

\footnotetext{
${ }^{1}$ The estimated Markov regime-switching model results for these three variables available upon request. The estimated model for British IP, in particular, is weak.
} 
Overall, these results suggest that neither America’s largest sector (agriculture), largest export crop (cotton), its largest manufacturing industry (textile mills) nor the world's largest economy (Britain) played a very prominent role in generating the First Great Moderation.

\section{E. THE END OF AMERICA’S FIRST GREAT MODERATION}

America's longest expansion ended in 1857 with a global financial crisis, a sharp reduction in bank credit and widespread declines in real estate values and stock prices. In the United States, a prominent cause cited by contemporaries for the 1857 financial panic was the failure of the Ohio Life Insurance and Trust Company. The American industrial sector contracted significantly during the recession, cumulatively falling nearly 8\% between 1856 and 1858. This was the largest decline in industrial production in the antebellum economy since the embargo of 1808.

The deep 1858 U.S. recession witnessed a significant contraction in transportation investment, which declined a cumulative 36\% between 1856 and 1858. Railroad and shipbuilding activity plummeted as the rates of returns of previous investment declined, inventories built, and the westward boom collapsed. While the Dred Scott case and several other events likely contributed to the severity of the downturn (Calomiris and Schweikart, 1991), it is apparent that more than a decade-long period of high investment had led to a buildup of private debt tied to rising asset values. Bank loans had grown faster than the broader economy during the expansion, rising from approximately \$250 million in 1843 to more than $\$ 680$ million at the end of 1857 . Following the panic bank lending fell off more than $16 \%$ in 1858, representing the most significant credit deleveraging since the early 1840s. America's First Great Moderation was over, with the coming onset of the American Civil War leading to a further increase in volatility in the real economy and the stock market.

\section{CONCLUSION}

The Great Moderation that commenced around 1984 is regarded by many economists as one of the longest periods of economic growth and low business cycle volatility in American history. In this paper, we identify another, much earlier period of high economic growth and low economic and financial market volatility. We identify America’s First Great Moderation—a recession-free, 16-year

period from 1841 until 1856 that represents the longest economic expansion in U.S. history. Productivity 
growth in the industrial sector was also exceedingly high; annual growth in industrial production averaged 8 percent per annum, the fastest pace of economic growth in the $19^{\text {th }}$ century.

We identify America’s antebellum “transportation revolution” as a primary reason for the First Great Moderation. We show that America’s First Great Moderation was primarily driven by transportation-goods investment, which we attribute to the wider adoption of general purpose technologies in both locomotives and shipbuilding. Our empirical results are consistent with endogenous growth models where the diffusion of general purpose technologies can create extended periods of high investment and minimal economic slumps as heterogeneous sectors adopt and expand on technologies such as steam power.

We also fail to find any compelling evidence that America's largest sector (agriculture), largest export crop (cotton), its largest manufacturing industry (textile mills) or the world's largest economy (Britain) played any important role in causing this moderation. While we cannot rule out that certain other factors-including western expansion, increased financial market integration, lower and stable tariffs, and state constitutional reforms (Wallis, 2005)—may have played some role during this time, they would have had to have worked through both the transportation sector and stock prices.

Although the first Great Moderation occurred more than 150 years ago, our Markov-switching models reveal that the low-volatility regime derived for the First Great Moderation are of similar relative magnitude and statistical significance to those estimated for the Second Great Moderation using comparable economic and stock-market data. This may not be terribly surprising given several similarities between the 1841-1856 and 1984-2006 periods.

First, both moderations experienced a change in the structure of the economy. The First Great Moderation witnessed the widespread adoption of important general purpose technologies_clipper and steam ships, railroads, and the telegraph—-that helped contribute to significantly larger markets for goods, labor and exports. The modern Great Moderation saw structural change in terms of the movement of production from goods to services, the IT revolution that led to better inventory management, and financial innovations that allowed households and firms to better smooth consumption and investment. Second, the first and second moderations have been characterized by improved economic policymaking. Many states during the first Great Moderation wrote new constitutions that redefined the rules of the game for business and the government, while tariff rates during this time were generally significantly lower and less volatile, especially in the 1850s. As for the modern period, many scholars have argued that good monetary policy was an important factor in the Great Moderation from 
1984-2007. Finally, both periods seem to have benefitted to some extent from good luck. While we do not observe significant changes in weather shocks or commodity prices during this period, the first Great Moderation did benefit from the discovery of gold in California. It also occurred during the era of Pax Brittanica - a period of global peace (Brown et al, 2005) and no major armed conflict in the United States. The second Great Moderation, on the other hand, appears to have been a period of generally low and stable oil prices coupled with few negative productivity shocks, at least up until 2007.

In summary, our analysis suggests that the First Great Moderation is an unparalleled period in the history of U.S. business cycles characterized by high economic growth rates and low business cycle volatility. Like the modern-day Great Moderation, the end of America's First Great Moderation was abrupt, pronounced, and notable for its magnitude following years of relative stability. Unlike the modern-day Great Moderation, however, America’s First Great Moderation occurred despite a low level of government spending, the absence of a central bank, and no marked improvement in price stability.

Ultimately, the findings in our paper may help alter not only how economic textbooks characterize the nineteenth-century economy, but today's business cycle as well. 


\section{BIBLIOGRAPHY}

Aghion, Philippe, George-Marios Angeletos, Abhijit Banerjee, and Kalina Manova. "Volatility and Growth: Credit Constraints and Productivity-Enhancing Investment,” NBER Working Paper 11349. 2005.

Aghion P and Howitt P. (1998) On the Macroeconomic Effects of Major Technological Change, in General Purpose Technologies and Economic Growth, E. Helpman, ed., Cambridge, MA: MIT Press, pp 121-144.

Aghion, Philippe, and Gilles Saint-Paul. (1998), “Virtues of Bad Times: Interaction Between Productivity Growth and Economic Fluctuations,” Macroeconomic Dynamics 2, 322-344.

Atack, Jeremy, Michael R. Haines, and Robert A. Margo. "Railroads and the Rise of the Factory: Evidence for the United States, 1850-1870.” NBER Working Paper 14410. 2008.

Atack, Jeremy and Robert A. Margo. “Agricultural Improvements and Access to Rail Transportation: The American Midwest as a Test Case, 1850-1860.” NBER Working Paper 15520. 2009.

Bodenhorn, Howard. “Capital Mobility and Financial Integration in Antebellum America.” The Journal of Economic History, Vol. 52 No. 3 (Sep. 1992), pp. 585-610.

. A History of Banking in Antebellum America: Financial Markets and Economic Development in an Era of Nation-Building. Cambridge, United Kingdom: Cambridge University Press. 2000.

Bernanke, Ben (2004). "The Great Moderation," remarks given at the meetings of the meetings of the Eastern Economic Association, Washington, DC, February 20.

Brown, William O., Richard C.K. Burdekin, and Marc D. Weidenmier. "Volatility in an era of reduced uncertainty: Lessons from Pax Brittanica.” Journal of Financial Economics, Vol. 79 (2006), pp. 693-707.

Burns, Arthur F. and Wesley C. Mitchell. Measuring Business Cycles. NBER. 1946. Electronic version found at http://www.nber.org/books/burn46-1.

Calomiris, Charles and Christopher Hanes. "Consistent Output Series for the Antebellum and Postbellum Periods: Issues and Preliminary Results.” The Journal of Economic History, Vol. 54 No. 2 (June 1994), pp. 409-422. and Larry Schweikart. "The Panic of 1857: Origins, Transmission, and Containment". The Journal of Economic History 51 (1991): pp. 808-810. 
Davis, Joseph. “A Quantity-Based Annual Index of US Industrial Production, 1790-1915: An Empirical Appraisal of Historical Business-Cycle Fluctuations”. Ph.D. dissertation, Duke University. 2002.

. “An Annual Index of US Industrial Production, 1790-1915.” The Quarterly Journal of Economics, Vol. 119, No. 4 (Nov. 2004), pp. 1177-1215.

. “An Improved Annual Chronology of U.S. Business Cycles,” Journal of

Economic History, 66 (2006), 103-121.

, Christopher Hanes, and Paul W. Rhode. "Harvests and Business Cycles in NineteenthCentury America.” The Quarterly Journal of Economics, vol. 124 no. 4 (2009), pp. 16751727.

Davis, Lance E. “The New England Textile Mills and the Capital Markets: A Study of Industrial Borrowing 1840-1860.” The Journal of Economic History, Vol. 20 No. 1 (Mar. 1960), pp. 1-30.

Ferrie, Joseph P. "Migration to the Frontier in Mid-Nineteenth Century America: A ReExamination of Turner's 'Safety Valve’.” Department of Economics, Northwestern University manuscript. 1997.

Fishlow, Albert. American Railroads and the Transformation of the Ante-bellum Economy. Cambridge, MA: Harvard University Press. 1965.

Gallman Robert E. “Gross National Product in the United States, 1834-1909,”in Dorothy S. Brady [ed.] Output, Employment, and Productivity in the United States after 1800, Studies in Income and Wealth Vol. 30 (New York: Columbia Univ. Press, 1966) pp. 376.

Goldin, Claudia and Robert A. Margo. "Wages, Prices, and Labor Markets Before the Civil War.” NBER Working Paper No. 3198, 1989.

Goetzmann, William N., Roger G. Ibbotson, and Liang Peng. NYSE History Research Project. http://icf.som.yale.edu/nyse/index.shtml

Historical Statistics of the United States. Cambridge University Press. 2000.

Irwin, Douglas A. “Antebellum Tariff Politics: Regional Coalitions and Shifting Economic Interests,” Journal of Law and Economics, 51(November 2008): 715-742.

Kindleberger, Charles P. 2000. Manias, Panics, and Crashes: A History of Financial Crises. $4^{\text {th }}$ ed. New York: John Wiley \& Sons. 
Margo, Robert A. “Labor Market Integration Before the Civil War.” NBER Working Paper 6643. 1998.

. "Regional Wage Gaps and the Settlement of the Midwest.” Explorations in Economic History, Vol. 36 (1999), pp. 128-143.

McConnell, Margaret, and Gabriel Perez-Quiros (2000). "Output Fluctuations in the United States: What Has Changed since the Early 1980s?" American Economic Review, 90, pp. 1464-76.

Miron, Jeffrey A., and Christina D. Romer, “A New Monthly Index of Industrial Production, 1884-1940,” Journal of Economic History, 50 (1990), 321-332.

Moore, Geoffrey H. and Victor Zarnowitz. 1986. The development and role of the National Bureau of Economic Research’s business cycle chronologies. In The American Business Cycle: Continuity and Change, ed. Robert J. Gordon, 735-79. NBER Studies in Business Cycles, vol. 25. Chicago: University of Chicago Press.

Rhode, Paul W. “Gallman’s Annual Output Series for the United States, 1834-1909.” NBER Working Paper No. 8860, 2002.

Romer, Christina D. “Remeasuring Business Cycles.” The Journal of Economic History, Vol. 54 (1994), pp. 573-609.

Rostow, W. W. The Stages of Economic Growth: A Non-Communist Manifesto. $3^{\text {rd }}$ Edition. Cambridge, United Kingdom: Cambridge University Press. 1990.

Rousseau, Peter L. “Jacksonian Monetary Policy, Specie Flows, and the Panic of 1837.” The Journal of Economic History, Vol. 62 No. 2 (Jun. 2002), pp. 457-488.

Schwert, 1990. “Indexes of United States stock prices from 1802 to 1987,” Journal of Business, 63 (July), 399-426.

Stock, James H. and Mark W. Watson. “Has the Business Cycle Changed and Why?” NBER Macroeconomics Annual, Vol. 17 (2002), pp. 159-218.

Taylor, George R. The Transportation Revolution 1815-1860. New York: Rinehart \& Co. 1951.

Temin, Peter. The Jacksonian Economy. New York: W. W. Norton \& Company, Inc., 1969.

Thorp, William L. Business Annals. NBER, 1926. Electronic version found at http://www.nber.org/books/thor26-1 
Turner, Frederick J. The Frontier in American History. New York: Henry Holt and Company, 1921. Hypertext version, ed. Michael W. Kidd, University of Virginia. http://xroads.virginia.edu/ hyper/turner/

Vandenbroucke, Guillame. “The US Westward Expansion.” International Economic Review, Vol. 49 No. 1 (Feb. 2008), pp. 81-110.

Watson, Mark W. "Business-Cycle Durations and Postwar Stabilization of the U.S. Economy." American Economic Review 84, no. 1 (1994): 24-46.

Zarnowitz, Victor. Business Cycles: Theory, History, Indicators, and Forecasting. NBER Studies in Business Cycles, vol. 27. Chicago: University of Chicago Press, 1992. 
Figure 1: Growth rates in annual Davis IP index, 1791-1915

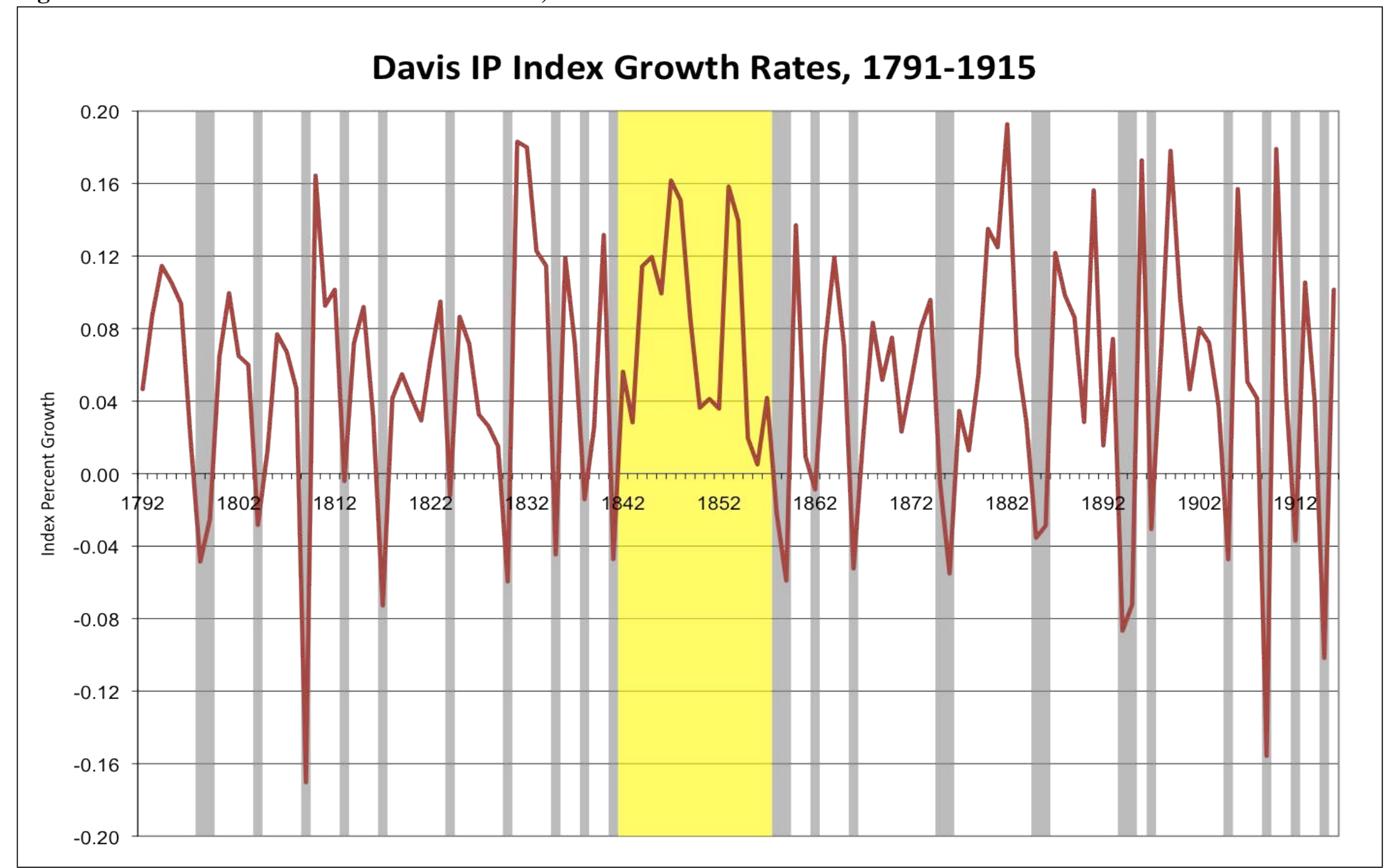

Notes: Gray areas represent declines in the Davis IP index, which we associate here with recessions, as in Davis (2006). The yellow area represents the First Great Moderation.

Sources: Davis (2002, 2004, 2006); authors' calculations. 
Figure 2: Monthly U.S. stock market returns, January 1826-December 1899

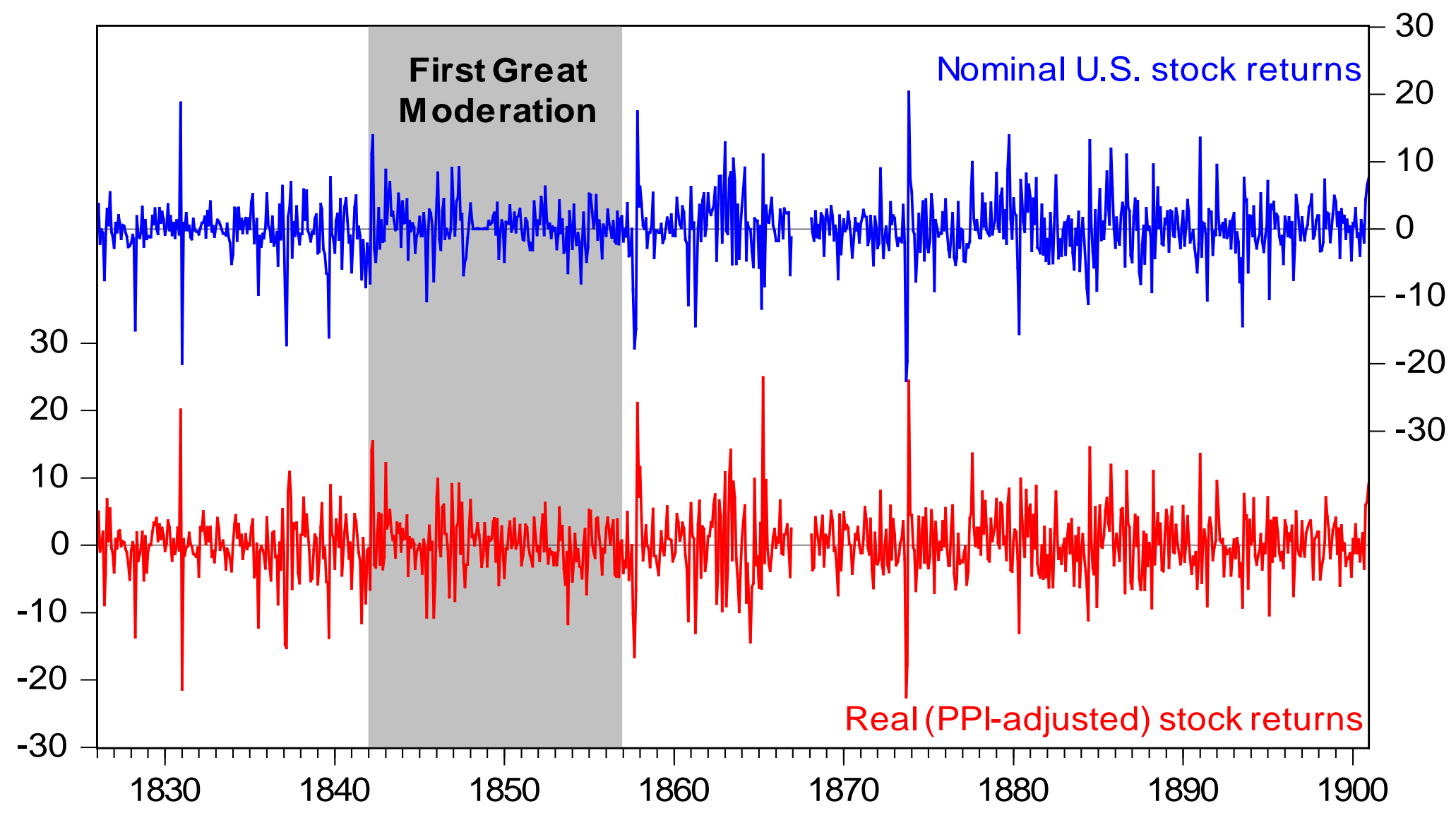

Sources and notes: Nominal returns reflect logarithmic percentage changes in the GIP-NYSE price-weighted capital appreciation index from the NYSE History Research Project. Observations for the calendar year 1867 are missing in the monthly GIP-NYSE index. Real returns were deflated by the wholesale price index. The GIP-NYSE index before 1826 is judged less reliable as the number of securities in the index often totals less than 30. For details, see Goetzmann, Ibbotson, and Peng (2000). 
Figure 3: Growth-to-Volatility Ratio in Industrial Production, 1810-2010

Line represents trailing 20-year averages in annual IP data

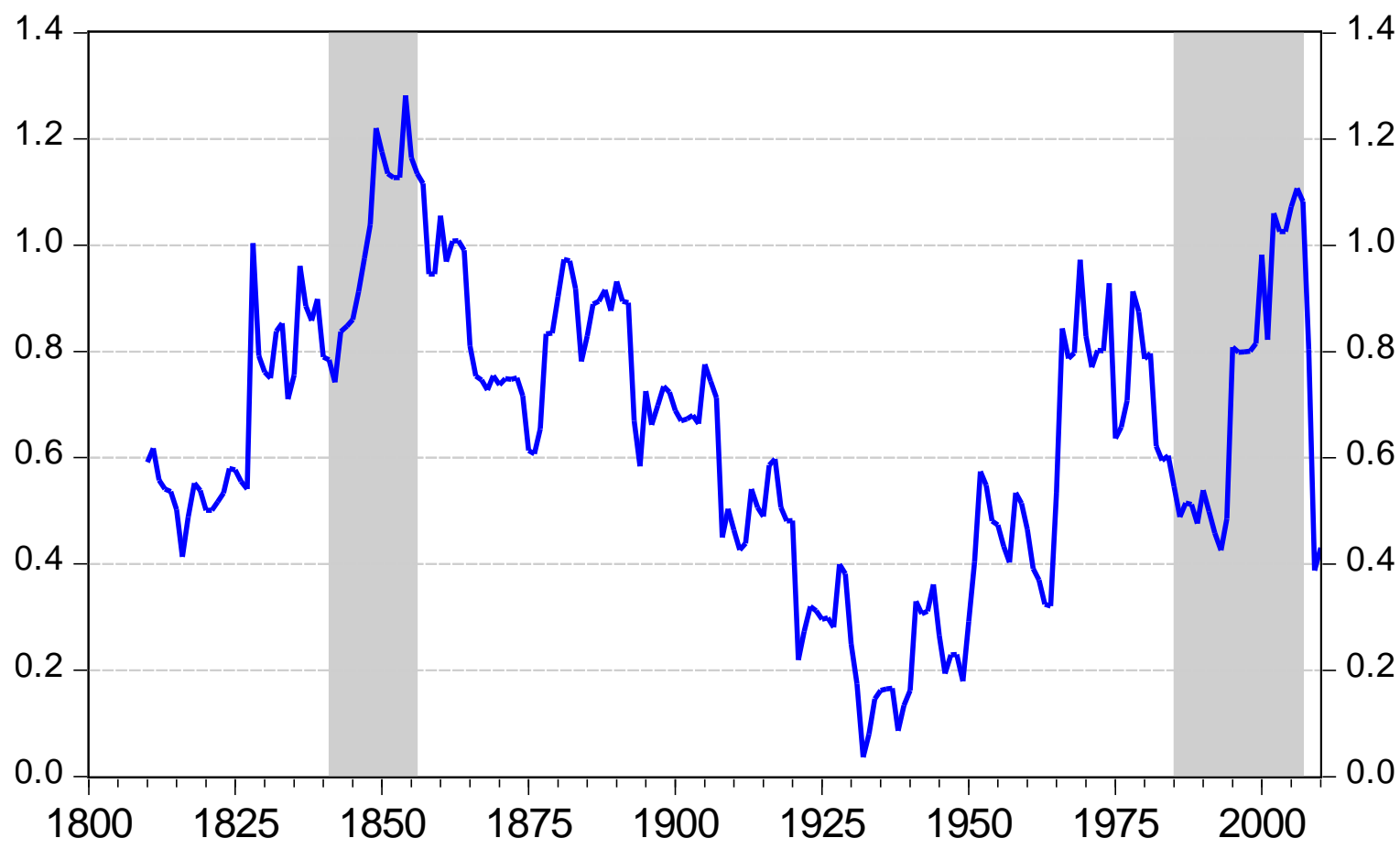

Notes: An annual IP index from 1790 through 2010 was created according to the procedures recommended in Davis (2004). Specifically, the annual Davis IP index was ratio-spliced to the MironRomer index in 1916 before ratio-splicing to the Federal Reserve IP index beginning in 1919. The resulting line above is a signal-to-noise ratio on this spliced series; a similar (and mirror-image) result is generally obtained using a coefficient of variation (CV), although the near-zero average IP growth during the 1930s distorts the CV scale. We stress that one should not attempt to conduct statistical volatility break-point tests on this spliced series before and after 1915 given changes in series comparability and reliability over time. For details, see Davis (2004, pp.1991-92).

Sources: Authors' calculations based on Davis (2002, 2004), Miron and Romer (1990), and U.S. Federal Reserve Board. 
Figure 4: Low-volatility state probabilities for annual U.S. IP growth rates

Panel A: Davis IP Index, 1792-1914, for Markov switching-variance, switching AR(1) model

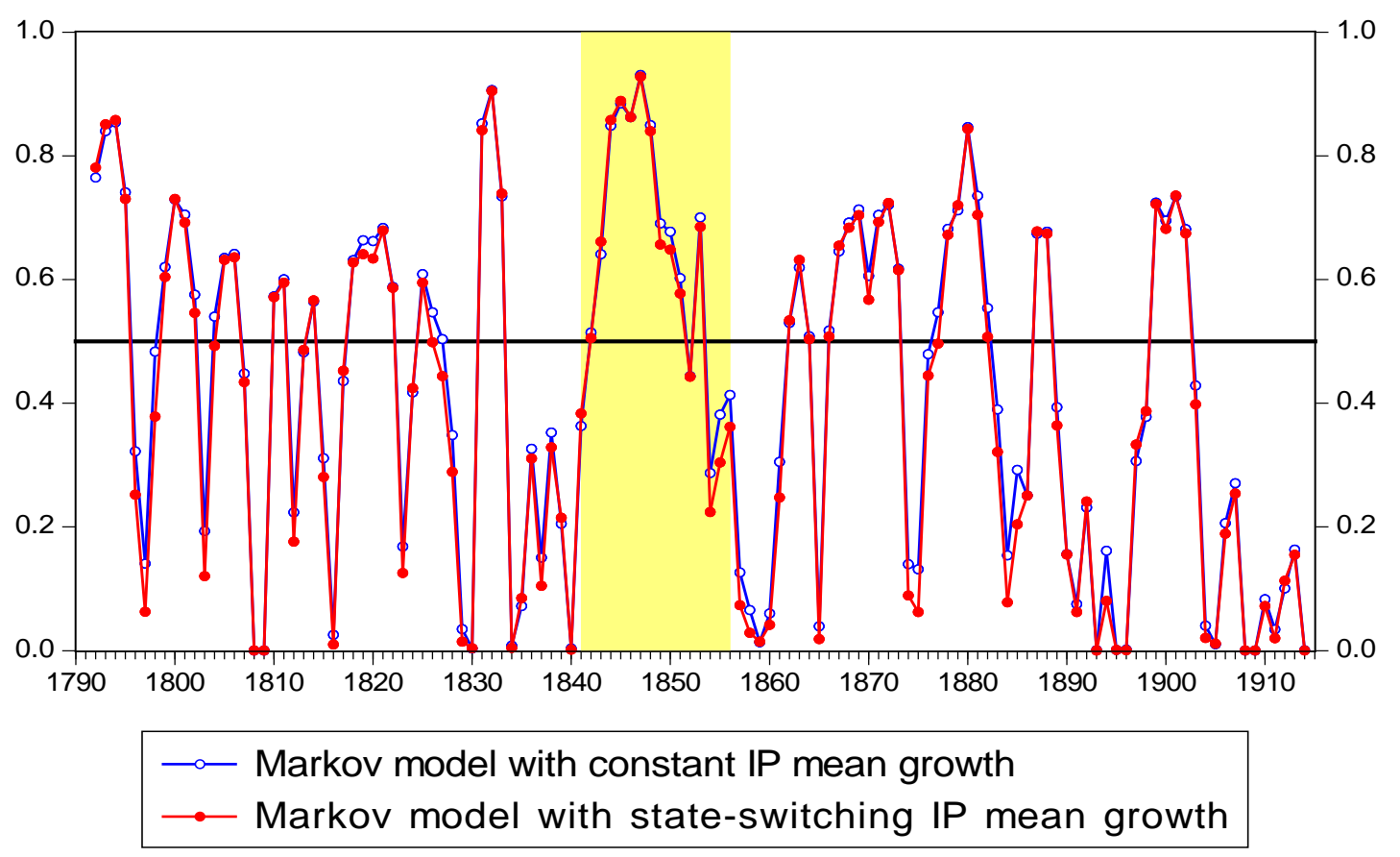

Panel B: FRB IP Index, 1950-2010 for Markov switching-variance, switching AR(1) model

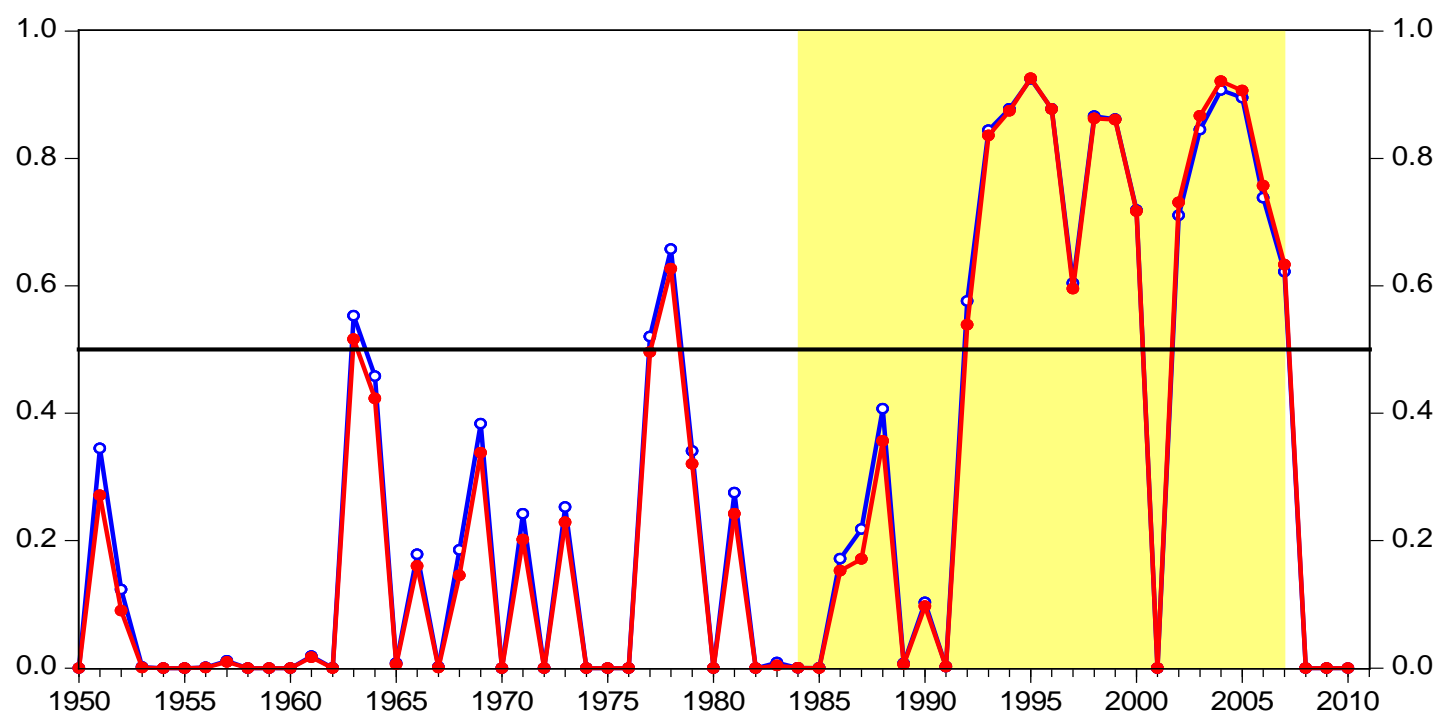

\section{- Markov model with constant IP mean growth rate Markov mode with state-switching IP mean growth rate}

Sources: Authors’ calculations. Probabilities are smoothed state probabilities. 
Figure 5: Ratio of conditional mean to conditional standard deviation in annual IP As estimated from a Markov regime-switching model for different periods

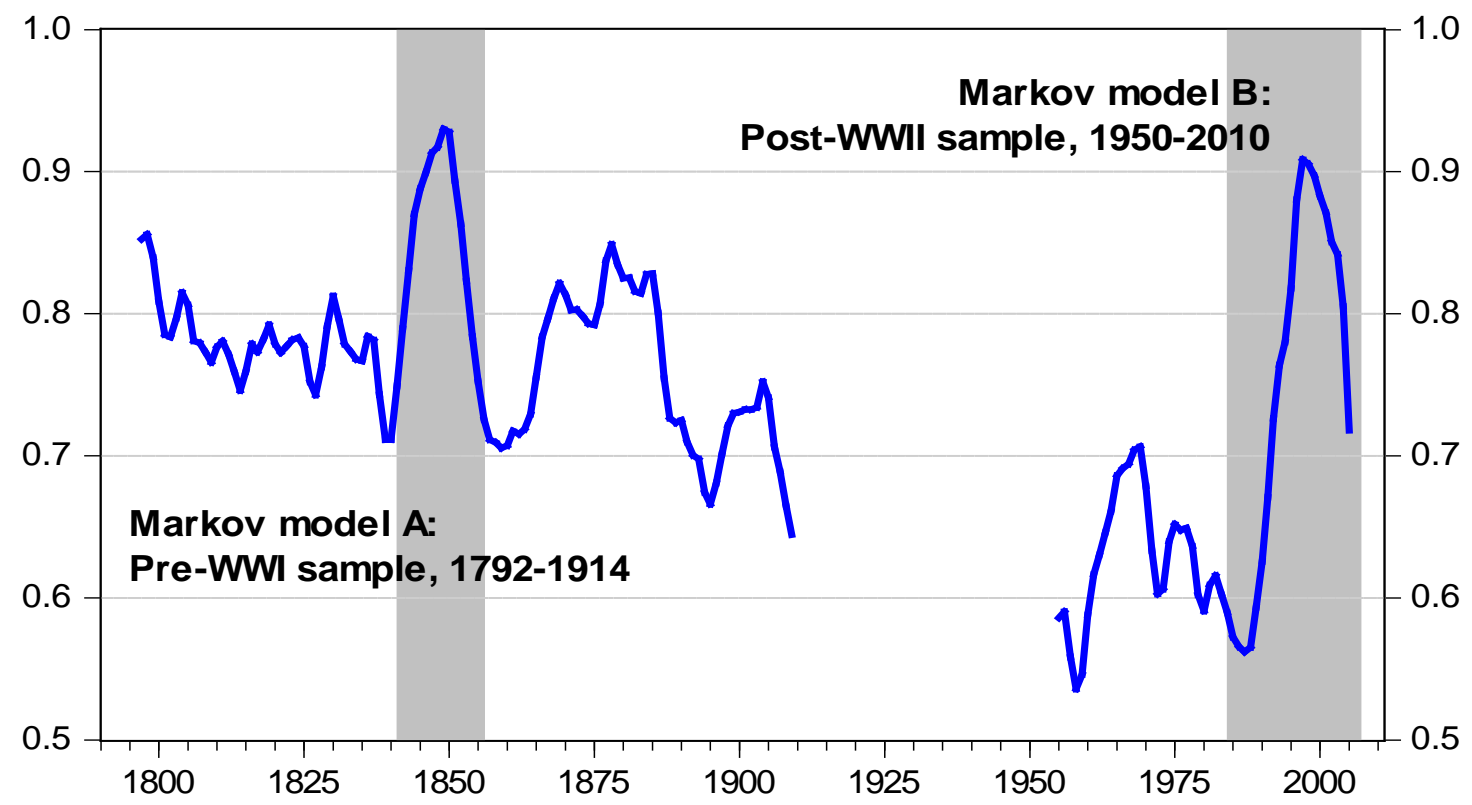

Note: Conditional means and standard deviations in each Markov regime-switching model were calculated based only on the filtered probabilities prior to time $t$. The Markov model was specified with switching volatilities and AR(1) terms but a constant mean; results are nearly identical with a switchingmean specification. Shaded regions demarcate America's First and Second Great Moderations. Lines reflect centered 10-year moving averages in the ratio of conditional mean to conditional standard deviation. 
Figure 6: Low-volatility state probabilities for monthly U.S. stock returns

Panel A: NYSE returns, January 1826 - December 1914 for switching-variance, switching AR(1) model

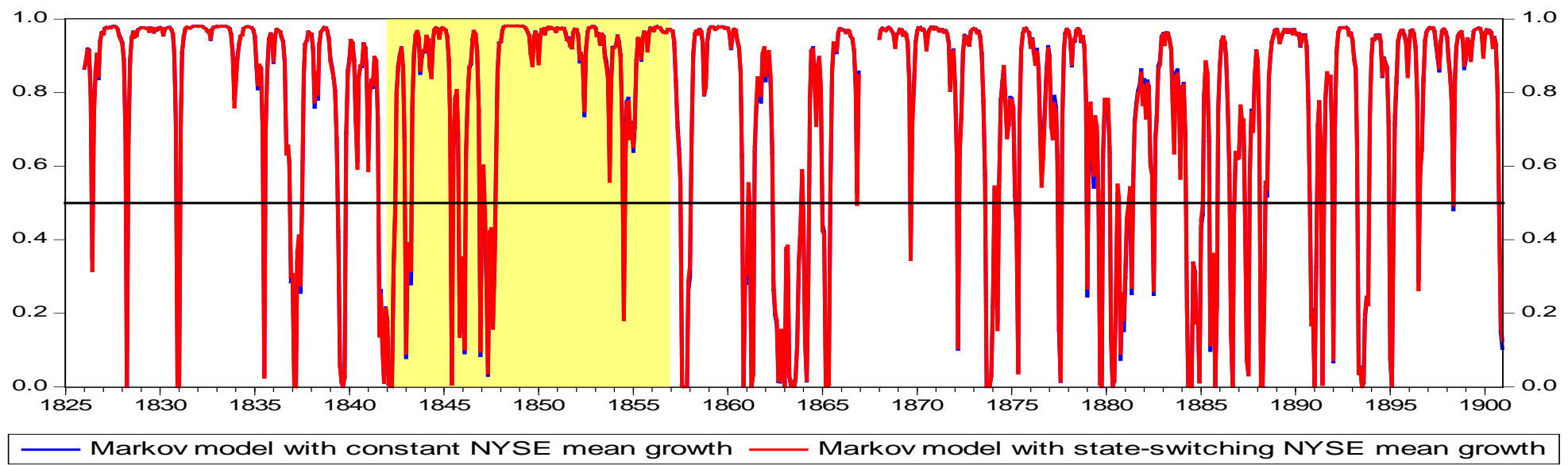

Panel B: S\&P500 returns, January 1950 - December 2010 for switching-variance, switching AR(1) model

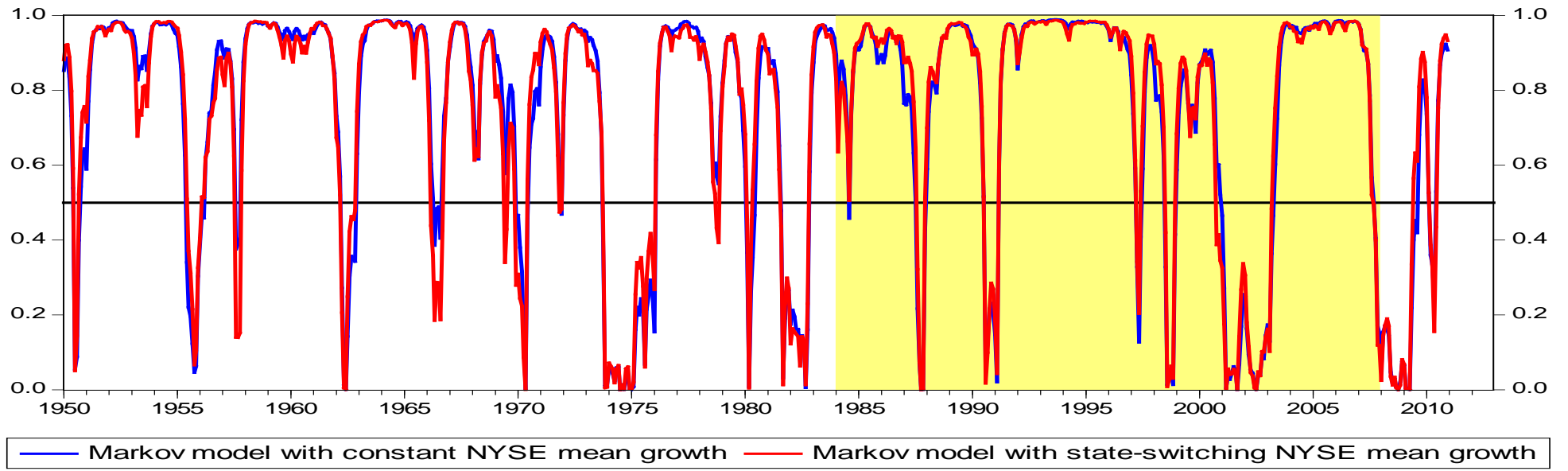

Sources: Authors' calculations. The Markov model in Panel A was fit over the January 1826-December 1914 period, excluding the missing NYSE observations for 1867 
Figure 7: 'Second-wave’ productivity boom during America's First Great Moderation

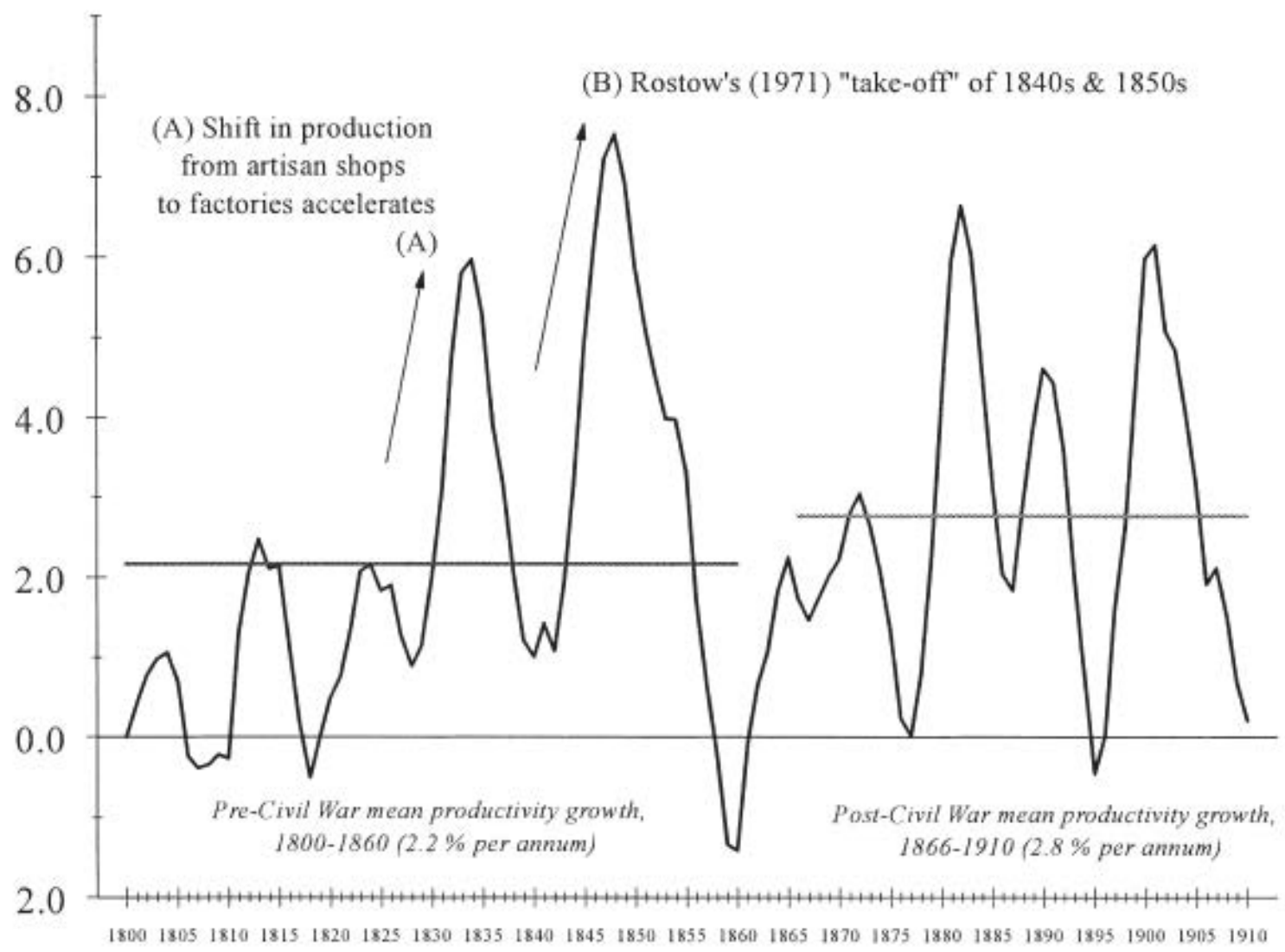

FiguRE III

Waves in Nineteenth-Century U. S. Industrial Productivity Growth

Plot represents running five-year centered moving averages of five-year annualized log growth rates in per capita industrial production. Productivity is defined on a per capita basis because annual labor-force estimates are unavailable.

Source: Taken directly from Davis (2004, 1197). 
Figure 8: Probabilities of low-volatility states for IP with and without key sectors

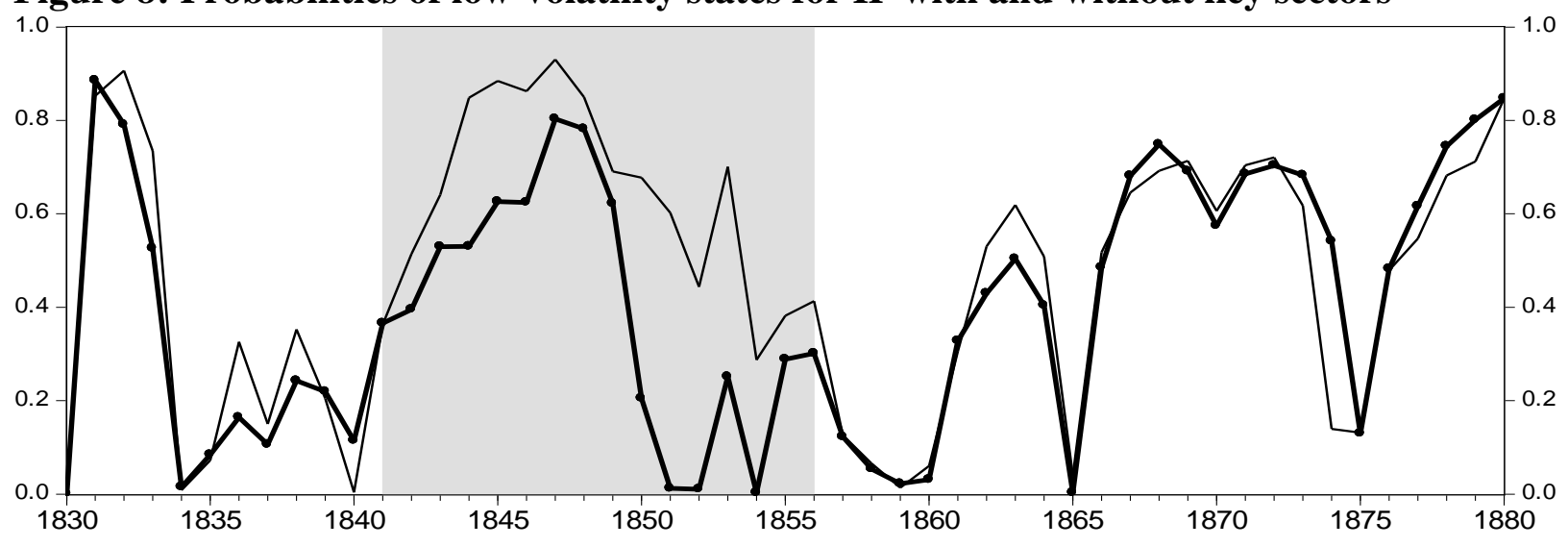

Dav is IP index

_ IP, excluding transportation
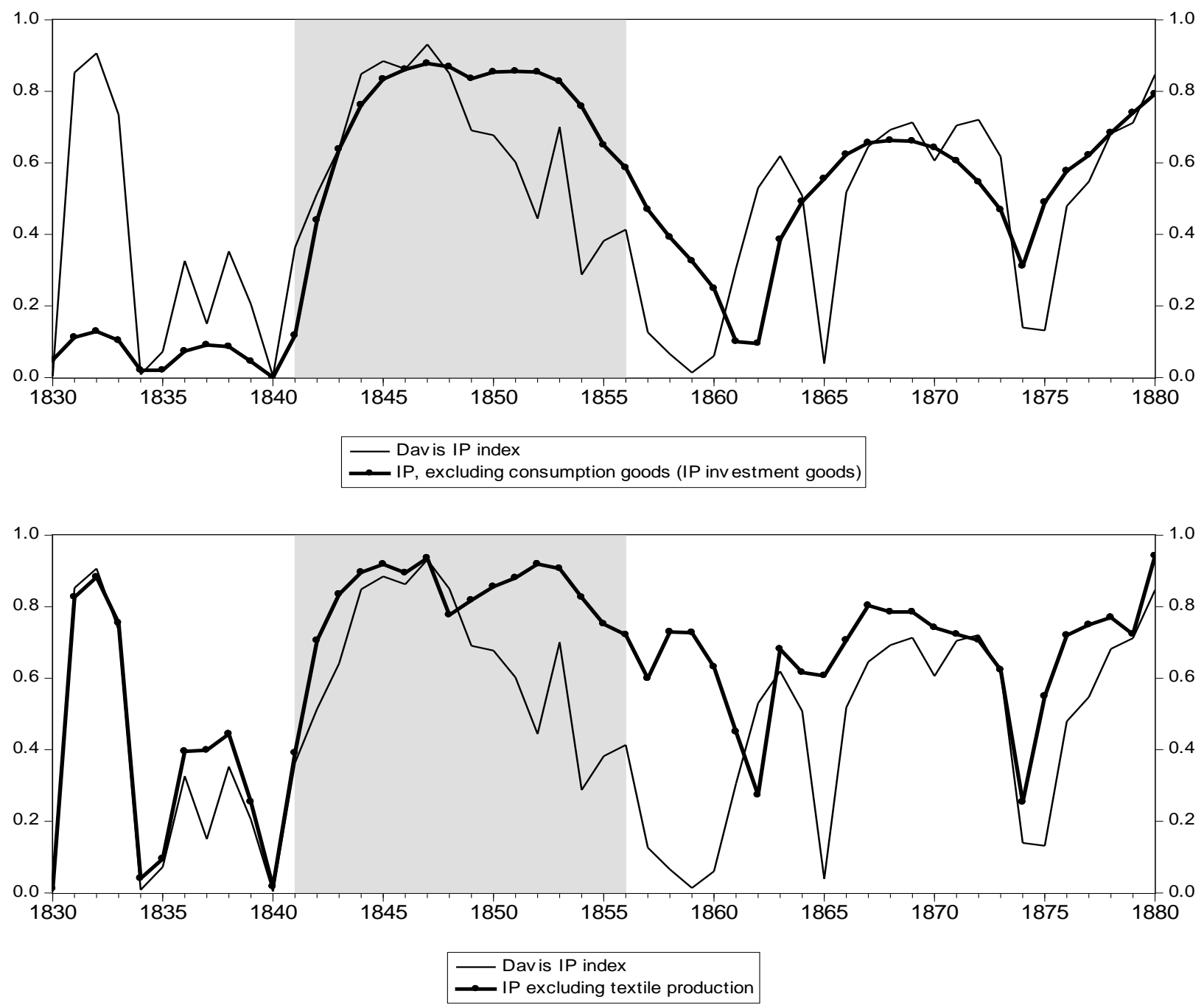

Notes: Smoothed low-volatility probabilities from Markov regime-switching model shown in Table 9. Figure does not show the entire 1792-1914 period simply to enhance clarity. 
Figure 9: Ratio of Markov conditional mean to standard deviation, various IP indexes

Davis IP index

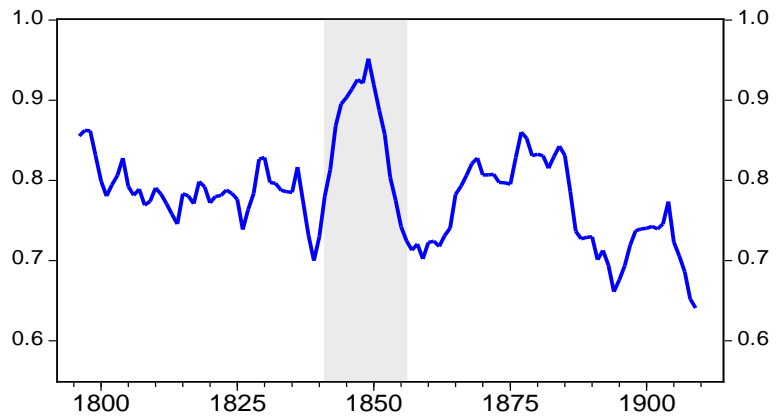

Davis IP index, investment goods only

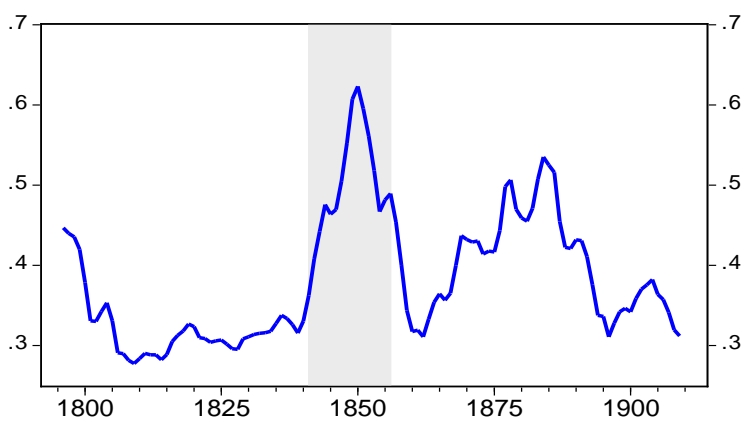

Davis IP index, ex transportation

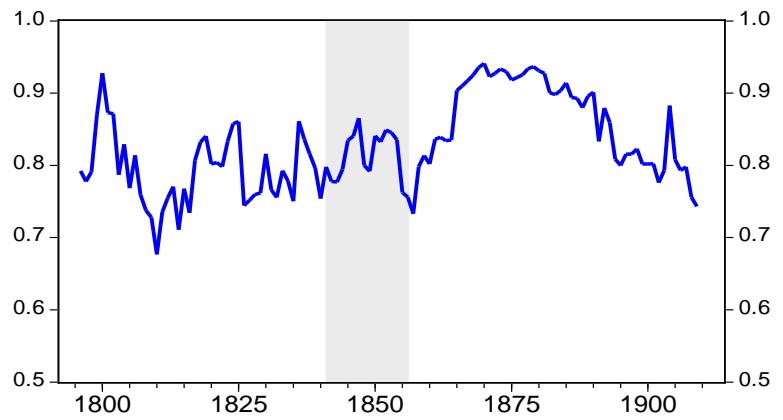

Davis IP index, ex textiles

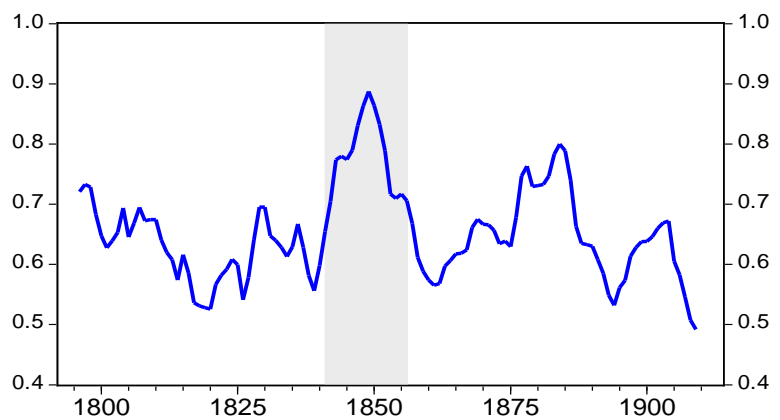

Note: Conditional means and standard deviations in each Markov regime-switching model were calculated based only on the filtered probabilities prior to time $t$. The Markov model was specified with switching volatilities and AR(1) terms but a constant mean; results are nearly identical with a switchingmean specification. Shaded regions demarcate America's First Great Moderations. Lines reflect centered 10 -year moving averages in the ratio of conditional mean to conditional standard deviation. 
Figure 10: Transportation Granger-caused all other IP during the Great Moderation Rolling 15-year F-statistics
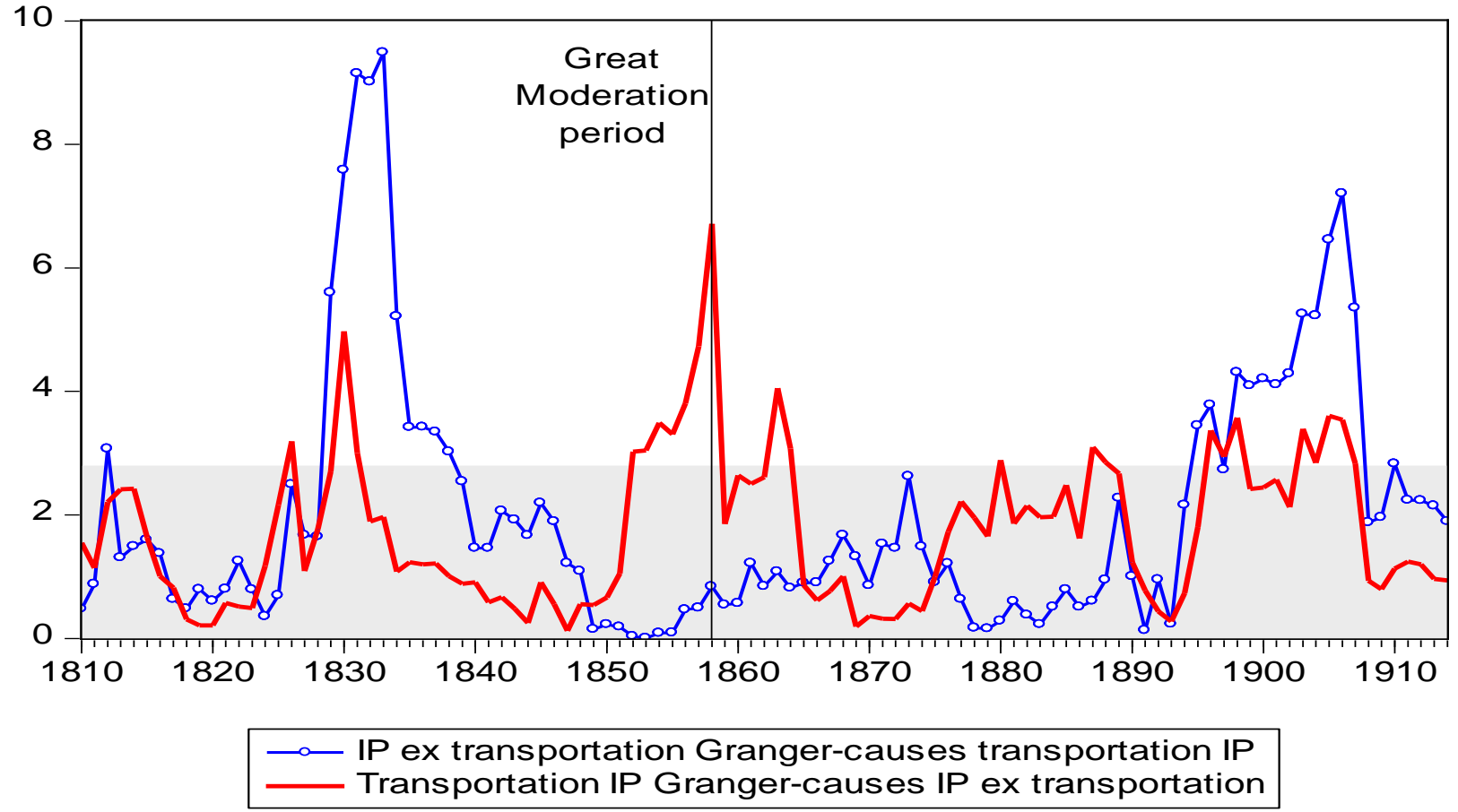

Notes: Figure displays rolling 15-year Granger-causality tests between annual growth rates in IP transportation index and all other IP. Years along the axis represent the end of the 15-year rolling period. The shaded region shows F-statistics below 2.8, the value for significance at the 10 percent level.

Figure 11: Estimated Low-Volatility States for Cotton Crop, British IP and Tariffs

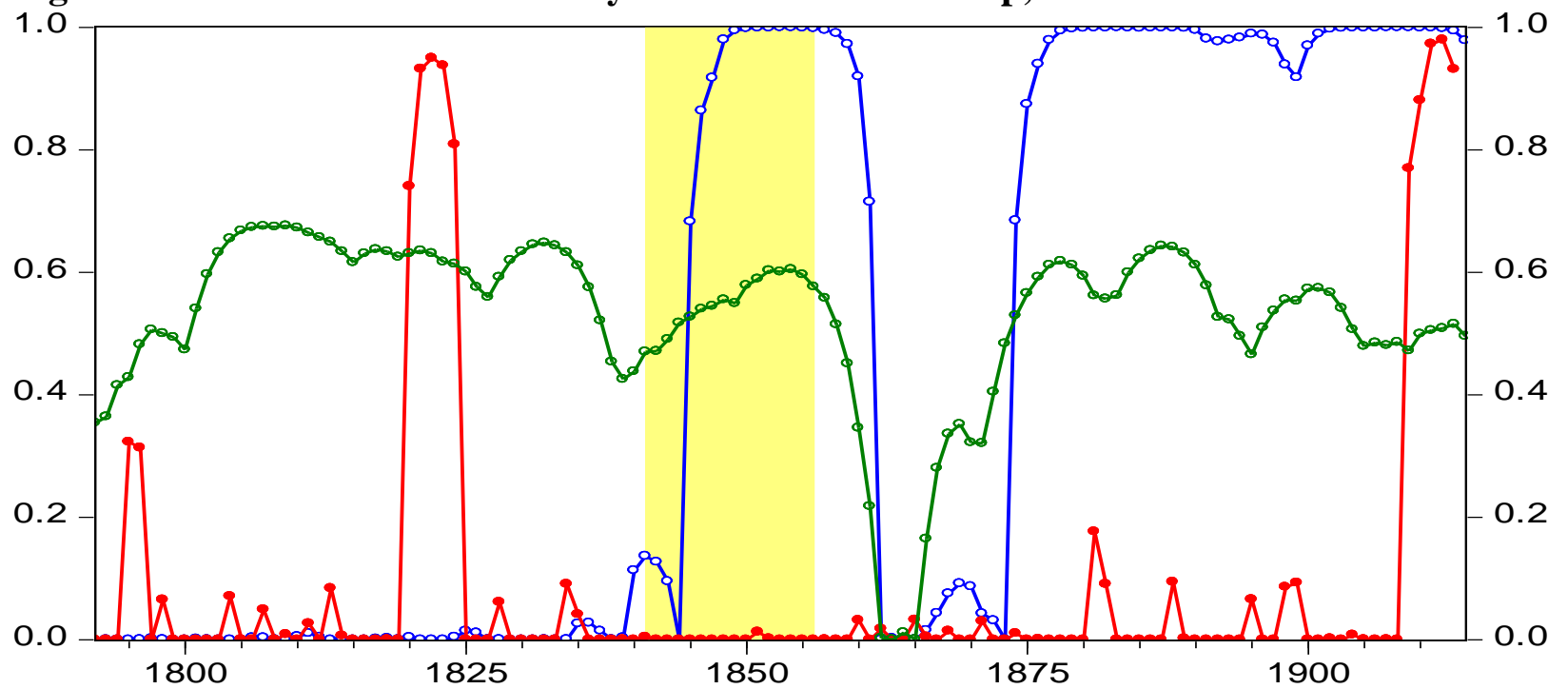

-

U.K. industrial production

U.S. cotton crop (lowest-vol state of 3 states)

Figures reflect smoothed probabilities from Markov model, as described in text. See also Figure 9. 
Table 1: Estimates of Trend Growth in U.S. Real GNP, 1834-1909

Annualized growth rates

Gallman real GNP, in levels

(Millions of 1860 dollars) between successive periods using:

\begin{tabular}{cccc} 
Decade & Single year & $\begin{array}{l}\text { Decade } \\
\text { average }\end{array}$ Single year & average \\
\hline
\end{tabular}

Census year

1834

1,403

1839

1,623

1,560

$2.95 \%$

1844

1,974

1,941

$4.00 \%$

$4.5 \%$

1849

2,429

2,549

$4.24 \%$

$5.6 \%$

1854

3,366

3,296

$6.74 \%$

$5.3 \%$

1859

4,100

$--$

$4.03 \%$

Gallman estimates do not exist for Civil War

Calendar year

1869

$$
5,347
$$

1879

8,336

8,417

$4.54 \%$

1889

$$
12,426
$$

12,604

$4.07 \%$

$4.1 \%$

1899

17,527

17,353

$3.50 \%$

$3.2 \%$

1909

$$
25,800
$$

--

$3.94 \%$ 
Table 2: Summary Statistics of Interest Rates in Major Cities, 1836-1856

\begin{tabular}{|c|c|c|c|c|c|c|c|}
\hline & & $\begin{array}{l}\text { Boston } \\
\text { (1) }\end{array}$ & $\begin{array}{l}\text { Boston } \\
\text { (2) }\end{array}$ & $\begin{array}{l}\text { New } \\
\text { York }\end{array}$ & Philadelphia & Charleston & $\begin{array}{l}\text { New } \\
\text { Orleans }\end{array}$ \\
\hline \multirow[t]{2}{*}{ Mean Rate } & $\begin{array}{l}1836- \\
1842\end{array}$ & 11.069 & 11.198 & 9.194 & 10.605 & 11.937 & 13.274 \\
\hline & $\begin{array}{l}1843- \\
1856\end{array}$ & 8.653 & 8.764 & 6.774 & 8.323 & 7.339 & 8.489 \\
\hline $\begin{array}{l}\text { Standard } \\
\text { Deviation }\end{array}$ & $\begin{array}{l}1836- \\
1842\end{array}$ & 6.477 & 7.542 & 3.744 & 4.527 & 5.074 & 5.766 \\
\hline \multirow{3}{*}{$\begin{array}{l}\text { Coefficient of } \\
\text { Variation }\end{array}$} & $\begin{array}{l}1843- \\
1856\end{array}$ & 3.085 & 3.530 & 2.080 & 3.051 & 2.181 & 3.111 \\
\hline & $\begin{array}{l}1836- \\
1842\end{array}$ & 0.585 & 0.674 & 0.407 & 0.427 & 0.425 & 0.434 \\
\hline & $\begin{array}{l}1843- \\
1856\end{array}$ & 0.357 & 0.403 & 0.307 & 0.367 & 0.297 & 0.366 \\
\hline
\end{tabular}

Sources: Bodenhorn (1992), authors’ calculations 
Table 3: Summary Statistics for U.S. Industrial Production, 1792-1914

Davis IP index, log growth rates

\begin{tabular}{llccc} 
Period & Dates & $\begin{array}{c}\text { Mean } \\
\text { growth (\%) }\end{array}$ & $\begin{array}{c}\text { Standard } \\
\text { deviation }\end{array}$ & $\begin{array}{c}\text { Coefficient } \\
\text { of variation }\end{array}$ \\
\hline Full sample & & & & \\
& $\mathbf{1 7 9 2 - 1 9 1 4}$ & $\mathbf{0 . 0 4 9}$ & $\mathbf{0 . 0 6 9}$ & $\mathbf{1 . 4 1}$ \\
Antebellum, pre-Great Moderation & $1792-1840$ & 0.047 & 0.067 & 1.45 \\
Great Moderation & $\mathbf{1 8 4 1 - 1 8 5 6}$ & $\mathbf{0 . 0 7 7}$ & $\mathbf{0 . 0 5 0}$ & $\mathbf{0 . 6 5}$ \\
Postbellum, pre-WWI & $1867-1914$ & 0.046 & 0.075 & 1.63 \\
& & & & \\
\hline
\end{tabular}

Memo: Statistical equivalence tests of mean and standard deviation

\begin{tabular}{|c|c|c|c|c|}
\hline \multirow{2}{*}{$\begin{array}{l}\text { Period } \\
\text { GM vs non-GM antebellum }\end{array}$} & \multicolumn{2}{|c|}{$\begin{array}{c}\text { Satterthwaite-Welch mean } \\
\text { equality t-test, } p \text {-value }\end{array}$} & \multicolumn{2}{|c|}{$\begin{array}{c}\text { Equality of variance } \mathrm{F} \text { - } \\
\text { test, } \mathrm{p} \text {-value }\end{array}$} \\
\hline & 0.04 & $* *$ & 0.098 & $*$ \\
\hline Across all 3 sub-samples & 0.12 & & 0.193 & \\
\hline Antebellum vs postbellum & 0.65 & & 0.355 & \\
\hline
\end{tabular}

Notes: *denotes significance at the 10 percent level; **denotes significance at the 5 percent level; ***denotes significance at the 1 percent level.

Sources: Davis (2004); authors' calculations. 
Table 4: Summary Statistics for Early U.S. Stock Returns, 1826-1914

U.S. stock prices, monthly price returns

\begin{tabular}{|c|c|c|c|c|}
\hline Period & Dates & $\begin{array}{c}\text { Mean } \\
\text { growth (\%) }\end{array}$ & $\begin{array}{l}\text { Standard } \\
\text { deviation }\end{array}$ & $\begin{array}{c}\text { Coefficient } \\
\text { of variation }\end{array}$ \\
\hline Full sample & 1826M1 - 1914M12 & 0.002 & 0.040 & 21.21 \\
\hline Antebellum, pre-Great Moderation & 1826M1 - 1840M12 & $(0.002)$ & 0.039 & (25.78) \\
\hline Great Moderation & 1841M1 - 1856M12 & 0.003 & 0.035 & 11.44 \\
\hline Postbellum, pre-WWI & 1868M1 - 1914M12 & 0.002 & 0.040 & 23.35 \\
\hline
\end{tabular}

Memo: Statistical equivalence tests of mean and standard deviation

\begin{tabular}{lccc} 
Period & $\begin{array}{c}\text { Satterthwaite-Welch mean equality } \\
\mathrm{t} \text {-test, } \mathrm{p} \text {-value }\end{array}$ & $\begin{array}{c}\text { Equality of variance } \mathrm{F} \text { - } \\
\text { test, } \mathrm{p} \text {-value }\end{array}$ \\
\cline { 2 - 3 } $\begin{array}{l}\text { GM vs non-GM antebellum } \\
\text { Across all 3 sub-samples }\end{array}$ & 0.19 & $\mathbf{0 . 0 0 8 * *}$ \\
Antebellum vs postbellum & 0.47 & $\mathbf{0 . 0 5 2} *$ \\
& 0.60 & 0.651
\end{tabular}

Notes: *denotes significance at the 10 percent level; **denotes significance at the 5 percent level; $* * *$ denotes significance at the 1 percent level.

Sources: NYSE History Research Project; authors’ calculations. 
Table 5: NBER Recession Chronology vs. Davis (2005) Recession Chronology

\begin{tabular}{|c|c|c|c|c|}
\hline \multicolumn{2}{|c|}{ NBER Chronology } & \multicolumn{2}{|c|}{ Davis (2005) Chronology } & \multirow{2}{*}{$\begin{array}{c}\text { Net change } \\
\text { to NBER phase } \\
\text { duration (in yrs.) }\end{array}$} \\
\hline Peak & Trough & Peak & Trough & \\
\hline \multicolumn{5}{|c|}{ Antebellum industrial cycles } \\
\hline 1802 & 1804 & 1802 & 1803 & less 1 \\
\hline 1807 & 1810 & 1807 & 1808 & less 2 \\
\hline 1811 & 1812 & 1811 & 1812 & \\
\hline 1815 & 1821 & 1815 & 1816 & less 5 \\
\hline 1822 & 1823 & 1822 & 1823 & \\
\hline 1825 & 1826 & & & no recession* \\
\hline 1828 & 1829 & 1828 & 1829 & \\
\hline 1833 & 1834 & 1833 & 1834 & \\
\hline 1836 & 1838 & 1836 & 1837 & less 1 \\
\hline 1839 & 1843 & 1839 & 1840 & less 3 \\
\hline 1845 & 1846 & \multirow{3}{*}{\multicolumn{2}{|c|}{$\begin{array}{c}\text { America's First Great } \\
\text { Moderation }\end{array}$}} & no recession \\
\hline 1847 & 1848 & & & no recession \\
\hline 1853 & 1855 & & & no recession* \\
\hline 1856 & 1858 & 1856 & 1858 & \\
\hline \multicolumn{5}{|c|}{ Civil War indus trial cycles } \\
\hline 1860 & 1861 & 1860 & 1861 & \\
\hline 1864 & 1867 & 1864 & 1865 & less 2 \\
\hline \multicolumn{5}{|c|}{ Postbellum industrial cycles } \\
\hline 1869 & 1870 & & & no recession* \\
\hline 1873 & 1878 & 1873 & 1875 & less 3 \\
\hline 1882 & 1885 & 1883 & 1885 & less 1 \\
\hline 1887 & 1888 & & & no recession* \\
\hline 1890 & 1891 & & & no recession* \\
\hline 1892 & 1894 & 1892 & 1894 & \\
\hline 1895 & 1896 & 1895 & 1896 & \\
\hline 1899 & 1900 & & & no recession* \\
\hline
\end{tabular}

Notes: All reference dates are calendar-year cycles. Bolded text reflects deviation from current NBER record. No recession* indicates a "growth recession," or a slowdown in the rate of economic growth based upon detrended values of the IP index. Victor Zarnowitz (1992) summarized the annual NBER peak-trough chronology. For the pre-WWI era, the annual chronology ultimately corresponds to Thorp's verbal assessment (1926, 113-45) later summarized in Burns and Mitchell (1946, 78, table 16) and Moore and Zarnowitz (1986, 746, table A.2).

Source: Davis (2006), Table 1. 
Table 6: Comparing the two Great Moderations using annual IP data

\begin{tabular}{|c|c|c|c|c|c|c|c|}
\hline \multirow[b]{2}{*}{ Year } & \multicolumn{3}{|c|}{ Davis IP index (annual frequency) } & \multicolumn{4}{|c|}{ Federal Reserve IP index (annual frequency) } \\
\hline & Log growth rate (\%) & 1-sided HP filter & 2-sided HP filter & Year & Log growth rate (\%) & 1-sided HP filter & 2-sided HP filter \\
\hline 1830 & 16.81 & 3.27 & (6.89) & 1980 & \begin{tabular}{|r|}
$(2.58)$ \\
\end{tabular} & (2.70) & 1.18 \\
\hline 1831 & 16.55 & 10.24 & 2.96 & 1981 & 1.33 & $(2.67)$ & 0.75 \\
\hline 1832 & 11.58 & 10.70 & 7.80 & 1982 & $(5.30)$ & $(6.66)$ & $(6.31)$ \\
\hline 1833 & 10.85 & 9.67 & 12.10 & 1983 & 2.71 & (3.56) & (5.48) \\
\hline 1834 & $\begin{array}{l}(4.57) \\
\end{array}$ & (1.60) & 1.26 & 1984 & 8.53 & 2.41 & 1.01 \\
\hline 1835 & 11.24 & 1.42 & 6.52 & 1985 & 1.20 & 1.35 & 0.04 \\
\hline 1836 & 6.88 & 0.46 & 7.69 & 1986 & 1.00 & 0.44 & (1.25) \\
\hline 1837 & (1.43) & (5.50) & 0.74 & 1987 & 5.04 & 2.40 & 1.37 \\
\hline 1838 & 2.53 & (6.33) & $(2.21)$ & 1988 & 5.03 & 3.46 & 3.90 \\
\hline 1839 & 12.37 & (0.08) & 4.55 & 1989 & 0.88 & 1.21 & 2.18 \\
\hline 1840 & $(4.84)$ & (7.06) & (6.18) & 1990 & 0.95 & (0.29) & 0.41 \\
\hline 1841 & 5.47 & (4.38) & (7.06) & 1991 & (1.56) & $(2.82)$ & $(4.03)$ \\
\hline 1842 & 2.78 & (4.03) & $(11.22)$ & 1992 & 2.79 & (1.43) & (4.36) \\
\hline 1843 & 10.82 & 1.64 & (7.98) & 1993 & 3.21 & $(0.16)$ & (4.51) \\
\hline 1844 & 11.29 & 5.43 & (4.86) & 1994 & 5.15 & 1.90 & (2.95) \\
\hline 1845 & 9.47 & 6.26 & $(4.02)$ & 1995 & 4.64 & 2.73 & (2.05) \\
\hline 1846 & 14.99 & 9.80 & 2.07 & 1996 & 4.35 & 2.86 & (1.48) \\
\hline 1847 & 14.03 & 10.67 & 7.17 & 1997 & 6.96 & 4.39 & 1.77 \\
\hline 1848 & 8.26 & 6.69 & 6.65 & 1998 & 5.65 & 4.17 & 3.92 \\
\hline 1849 & 3.56 & 0.62 & 1.73 & 1999 & 4.20 & 2.77 & 4.95 \\
\hline 1850 & 4.04 & $(3.00)$ & $(2.36)$ & 2000 & 3.94 & 1.49 & 6.12 \\
\hline 1851 & 4.73 & (4.64) & (5.36) & 2001 & (3.47) & $(4.17)$ & 0.33 \\
\hline 1852 & 15.92 & 1.84 & 3.32 & 2002 & 0.21 & (5.10) & (1.38) \\
\hline 1853 & 14.21 & 4.73 & 10.90 & 2003 & 1.26 & (4.62) & (1.67) \\
\hline 1854 & 3.41 & $(0.70)$ & 8.37 & 2004 & 2.30 & (3.28) & (0.56) \\
\hline 1855 & 1.59 & (5.27) & 4.70 & 2005 & 3.19 & (1.60) & 1.77 \\
\hline 1856 & 4.90 & (5.65) & 4.92 & 2006 & 2.17 & (1.04) & 3.44 \\
\hline 1857 & (1.48) & (9.51) & $(0.80)$ & 2007 & 2.63 & $(0.31)$ & 5.89 \\
\hline 1858 & $(5.54)$ & (13.81) & (10.34) & 2008 & (3.78) & (3.91) & 2.22 \\
\hline 1859 & 13.51 & (3.29) & $(0.79)$ & 2009 & $(11.83)$ & (11.04) & (9.33) \\
\hline 1860 & 1.73 & (3.84) & (3.05) & 2010 & 5.15 & (3.86) & (3.86) \\
\hline
\end{tabular}

Notes: Hodrick-Prescott filters used lambda=100. Sources: Authors’ calculations based on data from Davis (2004) and U.S. Federal Reserve. 


\section{Table 7: Markov Regime-Switching Models, Annual IP Growth, 1792-1914}

Both panels employ Markov model with switching variances and $A R(1)$ terms

\begin{tabular}{|c|c|c|c|c|c|c|c|c|c|}
\hline & \multicolumn{4}{|c|}{ Panel A: Constant mean growth } & & \multicolumn{4}{|c|}{ Panel B: Switching mean growth } \\
\hline \multirow[b]{2}{*}{ Parameter } & $\begin{array}{c}\text { State } \mathbf{V}_{\mathbf{1}} \\
\text { (Low Volatility) }\end{array}$ & \multirow{2}{*}{\multicolumn{2}{|c|}{$\begin{array}{c}\begin{array}{c}\text { State } \mathbf{V}_{\mathbf{2}} \\
\text { (High Volatility) }\end{array} \\
\text { Estimate } \\
\text { std error } \\
\text { [p-value] }\end{array}$}} & & & \multirow{2}{*}{$\begin{array}{c}\begin{array}{c}\text { State } \mathbf{V}_{\mathbf{1}} \\
\text { (Low Volatility) }\end{array} \\
\text { Estimate } \\
\text { std error } \\
\text { [p-value] }\end{array}$} & \multirow{2}{*}{\multicolumn{2}{|c|}{$\begin{array}{c}\begin{array}{c}\text { State } \mathbf{V}_{\mathbf{2}} \\
\text { (High Volatility) }\end{array} \\
\text { Estimate } \\
\text { std error } \\
\text { [p-value] }\end{array}$}} & \\
\hline & $\begin{array}{l}\text { Estimate } \\
\text { std error } \\
\text { [p-value] }\end{array}$ & & & & Parameter & & & & \\
\hline \multirow[t]{3}{*}{$\mu$} & \multicolumn{3}{|c|}{0.0429} & $* * *$ & $\mu$ & 0.0483 & $* * *$ & 0.0400 & $* * *$ \\
\hline & \multicolumn{3}{|c|}{0.0074} & & & 0.0150 & & 0.0113 & \\
\hline & \multicolumn{3}{|c|}{$[0.00]$} & & & {$[0.00]$} & & {$[0.00]$} & \\
\hline \multirow[t]{3}{*}{$\phi$} & 0.4111 & $* * *$ & $(0.2605)$ & $*$ & $\phi$ & 0.3767 & $* *$ & $(0.2375)$ & $*$ \\
\hline & 0.1061 & & 0.1380 & & & 0.1469 & & 0.1376 & \\
\hline & {$[0.00]$} & & {$[0.06]$} & & & {$[0.01]$} & & {$[0.09]$} & \\
\hline \multirow[t]{3}{*}{ c } & 0.0016 & $* * *$ & 0.0057 & $* * *$ & $\sigma$ & 0.0014 & $* * *$ & 0.0057 & $* * *$ \\
\hline & 0.0005 & & 0.0011 & & & 0.0005 & & 0.0011 & \\
\hline & {$[0.00]$} & & {$[0.00]$} & & & {$[0.01]$} & & {$[0.00]$} & \\
\hline Log-likelihood & 158.25 & & Ratio $\left(\sigma_{1} / \sigma_{2}\right)$ & 0.27 & Log-likelihood & 158.32 & & Ratio $\left(\sigma_{1} / \sigma_{2}\right)$ & 0.25 \\
\hline \multicolumn{5}{|c|}{ Transition probabilities matrix: (std. error, p-value): } & \multicolumn{5}{|c|}{ Transition probabilities matrix: (std. error, $p$-value): } \\
\hline & $0.67(0.13,0.00)$ & & $0.24(0.11,0.03)$ & & & $0.66(0.12,0.00)$ & & $0.23(0.10,0.02)$ & \\
\hline & $0.33(0.14,0.02)$ & & $0.76(0.11,0.00)$ & & & $0.34(0.13,0.01)$ & & $0.77(0.10,0.00)$ & \\
\hline \multirow{2}{*}{\multicolumn{5}{|c|}{ Expected duration of Regime \#1: 3.02 time periods }} & \multicolumn{5}{|c|}{ Expected duration of Regime \#1: 2.91 time periods } \\
\hline & & & \multicolumn{2}{|c|}{ Expected duration of Regime \#2: 4.13 time periods } & \multicolumn{5}{|c|}{ Expected duration of Regime \#2: 4.27 time periods } \\
\hline $\begin{array}{l}\text { denotes sign } \\
* \text { denotes sig } \\
* * \text { denotes s }\end{array}$ & $\begin{array}{l}\text { cance at the } \\
\text { icance at the } \\
\text { ificance at th }\end{array}$ & $\begin{array}{l}10 \text { pe } \\
5 \text { pe } \\
\text { ne } 1 \text { p }\end{array}$ & $\begin{array}{l}\text { ercent level; } \\
\text { ercent level; } \\
\text { percent level. }\end{array}$ & & & & & & \\
\hline
\end{tabular}




\section{Table 8: Markov Regime-Switching Models, Annual IP Growth in Different Eras}

Specification: Constant mean, switching variance, and switching AR(1) Markov model

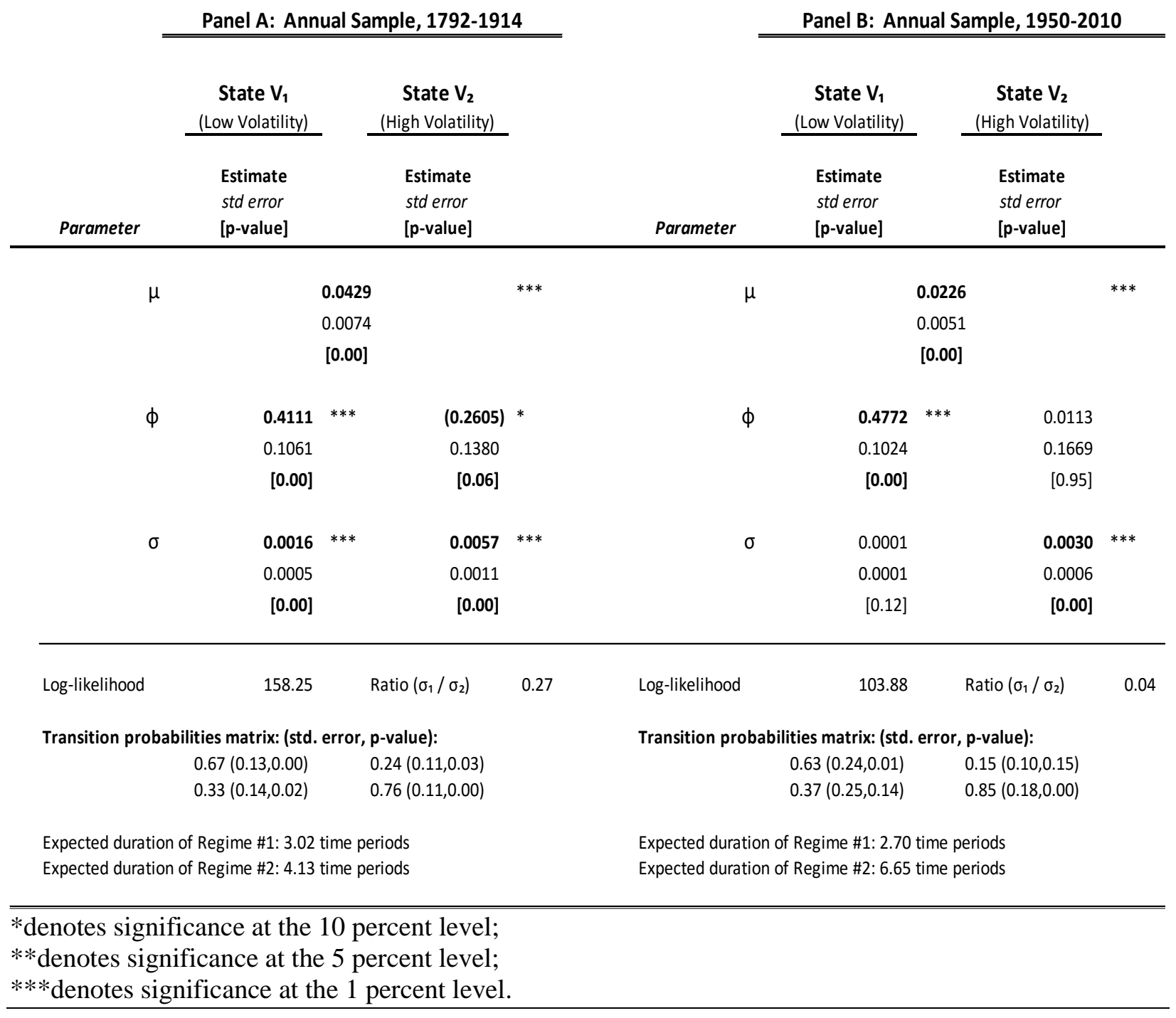




\section{Table 9: Markov Regime-Switching Models, Monthly U.S. Stock Returns}

Specification: Constant mean, switching variance, and switching AR(1) Markov model

\begin{tabular}{|c|c|c|c|c|c|c|c|c|c|c|}
\hline & \multicolumn{4}{|c|}{ Sample A: Monthly Data, 1826M1-1914M12 } & \multicolumn{6}{|c|}{ Sample B: Monthly Data, 1950M1-2010M12 } \\
\hline \multirow[b]{2}{*}{ Parameter } & $\begin{array}{c}\text { State } \mathbf{V}_{\mathbf{1}} \\
\text { (Low Volatility) } \\
\end{array}$ & & $\begin{array}{c}\text { State } \mathbf{V}_{\mathbf{2}} \\
\text { (High Volatility) }\end{array}$ & & \multirow{2}{*}{\multicolumn{2}{|c|}{ Parameter }} & $\begin{array}{c}\text { State } \mathbf{V}_{\mathbf{1}} \\
\text { (Low Volatility) }\end{array}$ & \multicolumn{3}{|c|}{$\begin{array}{c}\text { State } \mathbf{V}_{\mathbf{2}} \\
\text { (High Volatility) }\end{array}$} \\
\hline & $\begin{array}{l}\text { Estimate } \\
\text { std error } \\
\text { [p-value] }\end{array}$ & & $\begin{array}{l}\text { Estimate } \\
\text { std error } \\
\text { [p-value] }\end{array}$ & & & & $\begin{array}{l}\text { Estimate } \\
\text { std error } \\
\text { [p-value] }\end{array}$ & & $\begin{array}{l}\text { Estimate } \\
\text { std error } \\
\text { [p-value] }\end{array}$ & \\
\hline \multirow[t]{3}{*}{$\mu$} & \multicolumn{3}{|c|}{0.0018} & * & \multirow{2}{*}{\multicolumn{2}{|c|}{$\mu$}} & \multicolumn{3}{|c|}{0.0069} & $* * *$ \\
\hline & \multicolumn{3}{|c|}{0.0009} & & & & \multicolumn{3}{|c|}{0.0012} & \\
\hline & \multicolumn{3}{|c|}{$[0.06]$} & & \multicolumn{5}{|c|}{$[0.00]$} & \\
\hline & 0.0324 & & 0.0774 & & & $\phi$ & 0.2036 & $* * *$ & 0.2648 & $* * *$ \\
\hline & 0.0369 & & 0.0766 & & & & 0.0456 & & 0.0793 & \\
\hline & {$[0.38]$} & & {$[0.31]$} & & & & {$[0.00]$} & & {$[0.00]$} & \\
\hline & 0.0006 & $* * *$ & 0.0051 & $* * *$ & & $\sigma$ & 0.0006 & $* * *$ & 0.0028 & $* * *$ \\
\hline & 0.0000 & & 0.0004 & & & & 0.0000 & & 0.0003 & \\
\hline & {$[0.00]$} & & {$[0.00]$} & & & & {$[0.00]$} & & {$[0.00]$} & \\
\hline Log-likelihood & $2,032.31$ & & Ratio $\left(\sigma_{1} / \sigma_{2}\right)$ & 0.12 & Log-likelihood & & $1,474.50$ & & Ratio $\left(\sigma_{1} / \sigma_{2}\right)$ & 0.21 \\
\hline \multicolumn{5}{|c|}{ Transition probabilities matrix: (std. error, p-value): } & \multicolumn{6}{|c|}{ Transition probabilities matrix: (std. error, p-value): } \\
\hline & $0.91(0.03,0.00)$ & & $0.29(0.07,0.00)$ & & & & $0.95(0.04,0.00)$ & & $0.14(0.05,0.00)$ & \\
\hline & $0.09(0.02,0.00)$ & & $0.71(0.05,0.00)$ & & & & $0.05(0.02,0.00)$ & & $0.86(0.05,0.00)$ & \\
\hline \multicolumn{5}{|c|}{ Expected duration of Regime \#1: 11.65 months } & \multicolumn{6}{|c|}{ Expected duration of Regime \#1: 19.83 months } \\
\hline \multicolumn{5}{|c|}{ Expected duration of Regime \#2: 3.40 months } & \multicolumn{6}{|c|}{ Expected duration of Regime \#2: 7.06 months } \\
\hline
\end{tabular}

Notes: Stock return data reflect month-end values on the Yale / NYSE price-weighted capital appreciation monthly index (excludes dividends) through December, 1925, and spliced thereafter to month-end values of the S\&P500 Index (price index, excludes dividends, not a total return index).

*denotes significance at the 10 percent level;

**denotes significance at the 5 percent level;

***denotes significance at the 1 percent level. 
Table 10: Summary Statistics for IP Components and other Annual Data, 1792-1914

\begin{tabular}{|c|c|c|c|c|c|c|c|c|c|c|}
\hline \multirow[b]{2}{*}{ All variables in log growth rates } & \multirow[b]{2}{*}{$\begin{array}{c}1850 \\
\text { VA } \\
\text { weight } \\
(\%)\end{array}$} & \multicolumn{3}{|c|}{ Antebellum, pre-GM, $1792-1840$} & \multicolumn{3}{|c|}{ Great Moderation, 1841-1856 } & \multicolumn{3}{|c|}{ Postbellum, 1867-1914 } \\
\hline & & $\begin{array}{l}\text { Mean } \\
\text { growth } \\
(\%)\end{array}$ & $\begin{array}{l}\text { Standard } \\
\text { deviation }\end{array}$ & $\begin{array}{l}\text { Coefficient } \\
\text { of } \\
\text { variation }\end{array}$ & $\begin{array}{l}\text { Mean } \\
\text { growth } \\
(\%)\end{array}$ & $\begin{array}{l}\text { Standard } \\
\text { deviation }\end{array}$ & $\begin{array}{l}\text { Coefficient } \\
\text { of } \\
\text { variation }\end{array}$ & $\begin{array}{l}\text { Mean } \\
\text { growth } \\
(\%)\end{array}$ & $\begin{array}{l}\text { Standard } \\
\text { deviation }\end{array}$ & $\begin{array}{l}\text { Coefficient } \\
\text { of } \\
\text { variation }\end{array}$ \\
\hline Davis IP index & $100.0 \%$ & 0.047 & 0.067 & 1.45 & 0.077 & 0.050 & 0.65 & 0.046 & 0.075 & 1.63 \\
\hline IP, consumption goods & $60.2 \%$ & 0.054 & 0.083 & 1.53 & 0.063 & 0.052 & 0.83 & 0.045 & 0.046 & 1.02 \\
\hline IP, food \& agricultural products & $10.9 \%$ & 0.043 & 0.252 & 5.80 & 0.042 & 0.158 & 3.72 & 0.044 & 0.067 & 1.53 \\
\hline IP, cotton textiles & $21.8 \%$ & 0.061 & 0.149 & 2.45 & 0.069 & 0.161 & 2.32 & 0.047 & 0.106 & 2.25 \\
\hline IP, investment goods & $39.8 \%$ & 0.037 & 0.154 & 4.15 & 0.097 & 0.078 & 0.81 & 0.048 & 0.127 & 2.65 \\
\hline IP, transportation & $22.7 \%$ & 0.030 & 0.179 & 6.02 & 0.100 & 0.115 & 1.15 & 0.015 & 0.207 & 14.08 \\
\hline IP, metals & $12.9 \%$ & 0.052 & 0.231 & 4.48 & 0.070 & 0.178 & 2.55 & 0.070 & 0.131 & 1.87 \\
\hline IP index, ex food products & $89.1 \%$ & 0.048 & 0.085 & 1.77 & 0.081 & 0.052 & 0.63 & 0.046 & 0.085 & 1.82 \\
\hline IP index, ex textiles & $78.2 \%$ & 0.043 & 0.090 & 2.07 & 0.078 & 0.047 & 0.60 & 0.046 & 0.078 & 1.70 \\
\hline IP index, ex transportation & $77.3 \%$ & 0.056 & 0.080 & 1.44 & 0.070 & 0.063 & 0.91 & 0.051 & 0.063 & 1.24 \\
\hline \multicolumn{11}{|l|}{ Other annual variables } \\
\hline IP, U.K. & & 0.027 & 0.052 & 1.96 & 0.033 & 0.049 & 1.48 & 0.020 & 0.040 & 1.96 \\
\hline Wholesale prices & & $(0.008)$ & 0.088 & (11.30) & 0.006 & 0.069 & 10.89 & $(0.012)$ & 0.057 & (4.87) \\
\hline Cotton prices & & $(0.030)$ & 0.229 & $(7.75)$ & 0.013 & 0.227 & 17.83 & $(0.024)$ & 0.152 & (6.41) \\
\hline Immigration rate & & 0.086 & 0.375 & 4.34 & 0.023 & 0.345 & 14.79 & 0.007 & 0.328 & 46.41 \\
\hline Tariff rate (\%) & & 0.317 & 0.486 & 1.53 & 0.238 & 0.034 & 0.14 & 0.282 & 0.071 & 0.25 \\
\hline Cotton crop & & 0.118 & 0.185 & 1.57 & 0.047 & 0.186 & 3.92 & 0.044 & 0.191 & 4.34 \\
\hline \multicolumn{11}{|c|}{$\begin{array}{l}\text { Notes: All data expressed in logarithmic growth rates (except for tariffs) and are available back through } 1792 \text { except for IP metals (1828 with } \\
\text { introduction of pig iron) and the immigration rate (1821). The IP index for consumption goods includes the Davis (2004, Table II, p. 1188) sector } \\
\text { series for food products, textiles and apparel items, leather, printing \& publishing, and chemical and fuel products. The IP investment goods index } \\
\text { constitutes the remainder of the Davis IP index and includes metals, lumber, transportation equipment, and other small machinery categories } \\
\text { (musical instruments, scientific equipment, and ordnance). } \\
\text { Sources: Authors' calculations based on Davis (2002, 2004), Historical Statistics of the United States, and NBER Macrohistory Database. }\end{array}$} \\
\hline
\end{tabular}


Table 11: Markov Regime-Switching Models for Key IP Components Indexes, 1792-1914

Specification: Constant mean, switching variance, and switching AR(1) Markov model

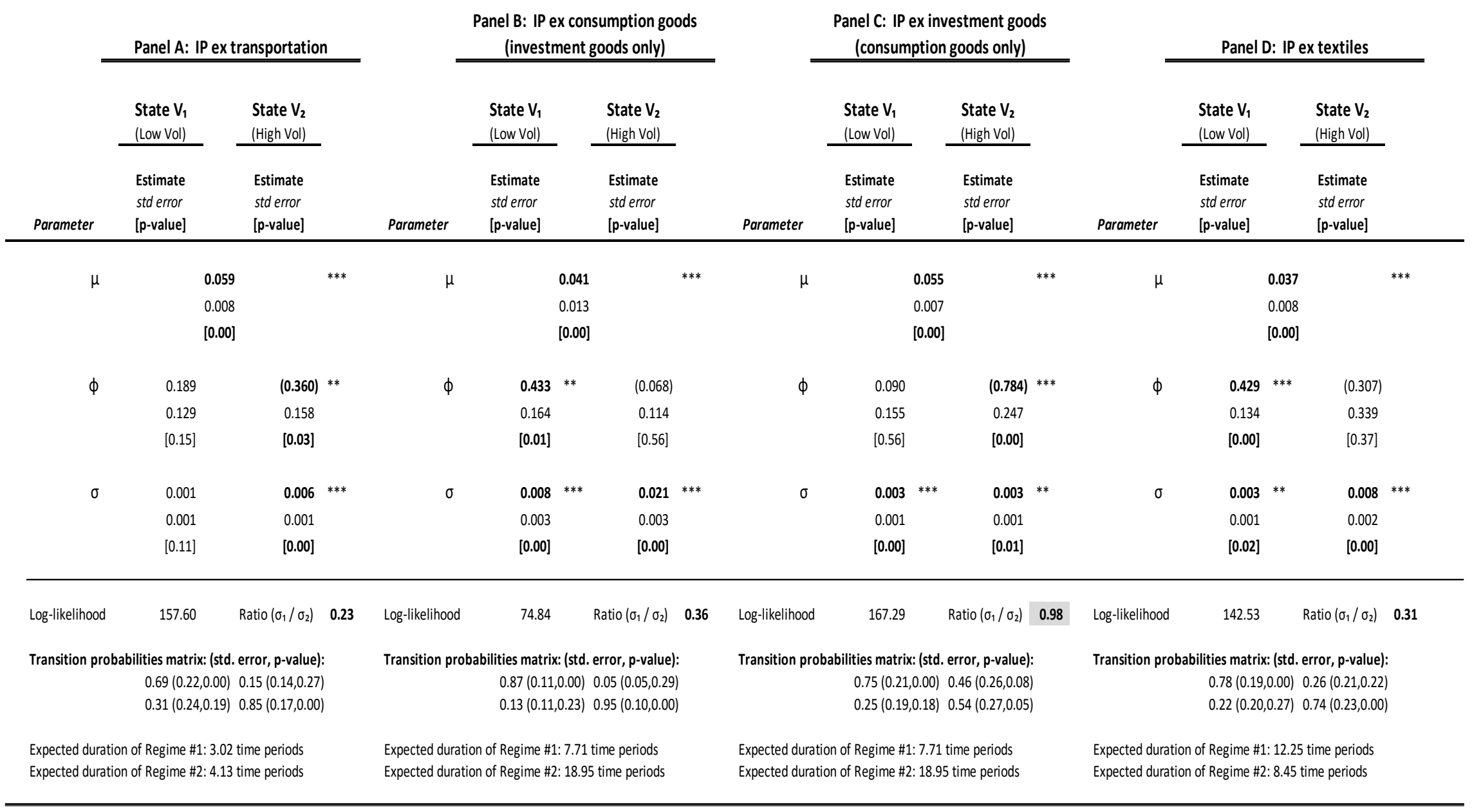

*, **, and $* * *$ denote significance at the 10,5 , and percent levels, respectively. 
Table 12: Granger-causality tests-IP sectors versus all other IP, various samples

\begin{tabular}{|c|c|c|c|c|c|c|c|c|c|c|c|}
\hline \multicolumn{2}{|c|}{ Null: $x_{t}$ does not Granger cause $y_{t}$} & \multicolumn{2}{|c|}{ Full sample, 1792 - 1914} & \multicolumn{2}{|c|}{ Antebellum, pre-GM } & \multicolumn{2}{|c|}{ Great Moderation } & & \multicolumn{3}{|c|}{ Postbellum, pre-WWI } \\
\hline$x_{t}$ & $y_{t}$ & F-stat & $p$-value & F-stat & $p$-value & F-stat & $p$-value & & F-stat & $p$-value & \\
\hline \multicolumn{12}{|l|}{$\mathbb{P}$, transportation } \\
\hline Transportation IP & All other IP & 0.94 & 0.39 & 0.40 & 0.67 & 6.03 & 0.01 & $* *$ & 1.64 & 0.21 & \\
\hline All other IP & Transportation IP & 2.59 & $0.08 *$ & 1.04 & 0.36 & 0.46 & 0.64 & & 3.59 & 0.04 & ** \\
\hline \multicolumn{12}{|l|}{$\mathbb{P}$, textiles } \\
\hline Textiles IP & All other IP & 0.13 & 0.88 & 0.21 & 0.81 & 0.27 & 0.76 & & 0.07 & 0.93 & \\
\hline All other IP & Textiles IP & 1.81 & 0.17 & 0.80 & 0.46 & 5.67 & 0.02 & $* *$ & 0.01 & 0.99 & \\
\hline \multicolumn{12}{|l|}{ IP, metals } \\
\hline Metals & All other IP & 2.15 & 0.12 & 0.12 & 0.89 & 0.24 & 0.79 & & 4.44 & 0.02 & ** \\
\hline All other IP & Metals & 0.86 & 0.43 & 2.16 & 0.20 & 3.84 & 0.05 & $* *$ & 0.27 & 0.77 & \\
\hline \multicolumn{12}{|c|}{ IP investment goods vs IP consumption goods } \\
\hline Consumption goods & Investment goods & 0.40 & 0.67 & 0.36 & 0.70 & 1.23 & 0.33 & & 0.41 & 0.66 & \\
\hline Investment goods & Consumption goods & 0.90 & 0.41 & 0.38 & 0.68 & 2.72 & 0.11 & & 2.37 & 0.11 & \\
\hline Transportation & Consumption goods & 0.46 & 0.64 & 0.06 & 0.95 & 4.75 & 0.03 & $* *$ & 0.57 & 0.57 & \\
\hline
\end{tabular}

Notes: VAR Granger-causality tests employ two lags for all series in all samples. "Great Moderation” sample ends in 1858 (rather than 1856) to account for the two-year lag. The post-bellum period begins in 1870 to remove the immediate effects of the end of the Civil War. The results for IP metals in the "Antebellum, pre-GM" sample begin in 1830 since the IP metals index begins in 1827 and the test requires two lags. ${ }^{*}, * *$, and $* * *$ denote significance at the 10,5 , and percent levels, respectively 
Table 13: Granger-causality tests-Alternative factors on IP indexes, various samples

\begin{tabular}{|c|c|c|c|c|c|c|c|c|c|c|c|}
\hline \multicolumn{2}{|c|}{ Null: $x_{t}$ does not Granger cause $y_{t}$} & \multicolumn{2}{|c|}{ Full sample, 1792 - 1914} & \multicolumn{3}{|c|}{ Antebellum, pre-GM } & \multicolumn{2}{|c|}{ Great Moderation } & \multicolumn{3}{|c|}{ Postbellum, pre-WWI } \\
\hline$x_{t}$ & $y_{t}$ & $F$-stat & $\mathrm{p}$-value & & F-stat & $p$-value & F-stat & $p$-value & F-stat & $p$-value & \\
\hline \multicolumn{12}{|l|}{ Cotton crop } \\
\hline Cotton crop & IP, textiles & 0.26 & 0.77 & & 0.61 & 0.55 & 3.35 & $0.07 *$ & 18.83 & 0.00 & $* * *$ \\
\hline Cotton crop & IP, investment goods & 0.02 & 0.98 & & 0.85 & 0.43 & 0.30 & 0.75 & 4.82 & 0.01 & $* *$ \\
\hline Cotton crop & IP, transportation & 0.14 & 0.87 & & 1.50 & 0.24 & 0.34 & 0.72 & 3.13 & 0.05 & $*$ \\
\hline Cotton crop & Davis IP index & 0.79 & 0.46 & & 1.25 & 0.30 & 1.02 & 0.39 & 8.33 & 0.00 & $* * *$ \\
\hline \multicolumn{12}{|l|}{ Tariff rate } \\
\hline Tariff rate & IP, textiles & 0.76 & 0.47 & & 2.39 & 0.10 & 0.85 & 0.45 & 0.93 & 0.40 & \\
\hline Tariff rate & $I P$, investment goods & 3.73 & 0.03 & $* *$ & 1.98 & 0.15 & 0.62 & 0.55 & 0.94 & 0.40 & \\
\hline Tariff rate & $\mathrm{IP}$, transportation & 1.20 & 0.30 & & 0.16 & 0.85 & 2.11 & 0.16 & 1.07 & 0.35 & \\
\hline Tariff rate & Davis IP index & 1.10 & 0.34 & & 0.46 & 0.64 & 0.58 & 0.57 & 1.00 & 0.38 & \\
\hline \multicolumn{12}{|l|}{ British IP } \\
\hline British IP & IP, textiles & 0.41 & 0.66 & & 1.90 & 0.16 & 0.12 & 0.89 & 6.20 & 0.00 & $* * *$ \\
\hline British IP & $I P$, investment goods & 0.18 & 0.84 & & 1.25 & 0.30 & 0.65 & 0.54 & 1.13 & 0.33 & \\
\hline British IP & IP, transportation & 0.41 & 0.67 & & 1.79 & 0.18 & 1.40 & 0.28 & 2.11 & 0.13 & \\
\hline British IP & Davis IP index & 0.20 & 0.82 & & 1.26 & 0.29 & 0.65 & 0.54 & 1.46 & 0.25 & \\
\hline
\end{tabular}

Notes: See Table 12. 